\title{
Soil microbial communities respond to an environmental gradient of grazing intensity in south Patagonia Argentina
}

\author{
Toledo Santiago $^{\text {a,*, }}$ Peri Pablo L ${ }^{\mathrm{a}, \mathrm{b}}$, Correa Olga $\mathrm{S}^{\mathrm{c}}$, Gargaglione Veronica ${ }^{\mathrm{a}, \mathrm{b}}$, \\ Gonzalez-Polo Marina ${ }^{\mathrm{d}}$ \\ ${ }^{\text {a } U n i v e r s i d a d ~ N a c i o n a l ~ d e ~ l a ~ P a t a g o n i a ~ A u s t r a l ~(U N P A)-C I T-C O N I C E T, ~ S a n t a ~ C r u z, ~ A r g e n t i n a ~}$ \\ ${ }^{\mathrm{b}}$ Instituto Nacional de Tecnología Agropecuaria (INTA), Argentina \\ ${ }^{\mathrm{c}}$ Universidad de Buenos Aires (UBA), Facultad de Agronomía, Departamento de Biología Aplicada y Alimentos, Argentina \\ ${ }^{\mathrm{d}}$ INIBIOMA, CONICET-Universidad Nacional del Comahue, Bariloche, Argentina
}

\section{A R T I C L E I N F O}

\section{Keywords:}

Microbial biomass carbon

Soil respiration

Fungi and bacteria

Microbial coefficient

Livestock stocking

Grassland

\begin{abstract}
A B S T R A C T
Soil microorganisms communities regulate key functions in terrestrial ecosystems and contributes to the formation of stable organic matter and hence climate change mitigation. The structure, diversity and activity of soil microbial communities are influenced by the quantity and quality of organic compounds entering soils through the contribution of their root exudates and plant litter, which the microorganisms use as a substrate for biosynthesis and energy source. However, grazing effect on the soil microorganisms showed variable results dependent on the ecosystem under study. One of the main challenges of this millennium is the sustainability of agricultural production, especially in fragile soils such as those present in Patagonia. Therefore, our objective was to evaluate the responses of microbial biomass carbon (MBC), soil basal respiration (SBR), the derived coefficients and the abundance of fungi and bacteria under contrasting long-term grazing intensities in an environmental gradient. The study was established in three ecological areas Mata Negra Thicket (MNT), Dry Magellanic Steppe (DMS) and Humid Magellanic Steppe (HMS) with two grazing intensities. Soil samples were taken over two years in different seasons (autumn, winter, spring and summer). Results showed that biotic and abiotic factors (temperature and precipitation), plant communities and soil characteristics modulated the microbial structure and function in ecological area. On the other hand, high grazing intensity decreased the MBC and microbial coefficient (qM). There was a seasonal and interannual dynamic in the MBC and the bacteria and fungal communities, attributed mainly to temperature and precipitation. The results indicated that the effect of grazing intensity in soil microbial communities depends largely on intrinsic characteristics of each ecological area defined by the environmental gradient.
\end{abstract}

\section{Introduction}

At global scale, grassland ecosystems store around $28-37 \%$ of soil organic carbon (SOC), having a key role in the carbon cycle (Lei et al., 2016). A small fraction (1-4\%) of the SOC corresponds to the carbon of the microbial biomass (MBC) (Sparling, 1992) which regulates key functions in terrestrial ecosystems (Ponge, 2015), such as nutrient cycling (Franzluebbers et al., 1995), decomposition of organic matter (Araújo et al., 2008), mineralization of nutrients (Manzoni and Porporato, 2009) and detoxification of toxic compounds (Abdu et al., 2017), between others. In addition, it has been proposed that the soil microbiome contributes to the formation of stable organic matter (Liao and Boutton, 2008) and hence could contribute to mitigation of climate change.

The structure, diversity and activity of soil microbial communities are influenced by the physico-chemical properties of soils and by the quantity and quality of organic compounds entering soils (Lauber et al., 2008). Plants can have a positive effect on microorganisms through the contribution of their root exudates and plant litter, which the microorganisms use as a substrate for biosynthesis and energy source (Dennis et al., 2010).

Multiple effects of long-term grazing on grasslands across Southern

\footnotetext{
* Corresponding author. 9400, Río Gallegos, Argentina.

E-mail addresses: toledo.santiago@inta.gob.ar (T. Santiago), peri.pablo@inta.gob.ar (P. Pablo L), correa@agro.uba.ar (C. Olga S), gargaglione.veronica@inta.gob. ar (G. Veronica), marina.gonzalezpolo@comahue-conicet.gob.ar (G.-P. Marina).
} 
Patagonia have been described by several studies (Peri, 2011; Peri et al., 2016a, 2018). The compositional vegetation changes induced by grazing affect the quantity and quality of plant litter input to soil (Golluscio et al., 2009; Liu et al., 2015; Zhou et al., 2017). Also, plants under severe grazing intensity reduce carbon allocation to belowground growth (Holland et al., 1992, 1996; Bardgett et al., 1998; Bais et al., 2006), and therefore affects the substrate availability for soil microorganisms (Spehn et al., 2000; Bardgett et al., 2002; Stark et al., 2012). Studies of grazing effects on microbial biomass carbon (MBC) showed variable results, while in some of them there are no changes (Raiesi and Asadi, 2006; Teague et al., 2011), in others a decrease is observed (Golluscio et al., 2009; Zhou et al., 2017) or an increase according to grazing intensity (Hamilton and Frank, 2001; Reeder and Schuman, 2002). Moreover, grazing intensity alters the abundance and composition of soil fungi and bacteria, in a manner dependent on the ecosystem under study (Bardgett et al., 2001; Patra et al., 2005; Weber et al., 2013).

In southern Patagonia (province of Santa Cruz), natural grasslands cover $85 \%$ of the total area, where different ecological regions had been defined based on vegetation types and climate (Peri et al., 2016b). Ecological regions are mostly arid and semi-arid, with a west-east gradient of decreasing rainfall from 1000 to $200 \mathrm{~mm}$ per year (Peri et al., 2013). In addition, vegetation patterns differ according to this rainfall gradient (Jobbágy et al., 2002), soil type and topography (Bisigato and Bertiller, 2004). Extensive sheep farming is the main activity with a total of $2,770,000$ sheep, livestock stocking varies from 0.13 to 0.75 heads ha $^{-1}$ year $^{-1}$ depending on ecological regions and intensity of use (Peri et al., 2013).

One of the main challenges of this millennium is the sustainability of agricultural production, especially in fragile soils such as those present in Patagonia. To ensure sustainability, periodic soil monitoring programs must be addressed, and sensitive and fast-responding indicators must be chosen as an early "warning" signal of ecosystem deterioration (Schloter et al., 2018). Microbial biomass carbon (MBC), soil basal respiration (SBR), SOC, together with the metabolic and microbial coefficient have had been used for soil monitoring (Schloter et al., 2018). MBC, an active fraction of soil organic matter, is the reservoir of plant nutrients (nitrogen, phosphorous and sulfur) and it is more susceptible to management practices than other soil fractions (Sparling, 1992; Truu et al., 2008). Soil basal respiration (SBR) measured as the production of $\mathrm{CO}_{2}$ released from the soil directly reflects microbial activity and indirectly the availability of labile substrates (Noellemeyer et al., 2008). The metabolic coefficient $\left(\mathrm{qCO}_{2}\right)$ (respiration-biomass ratio) provides information on the metabolic efficiency of soil microorganisms (Anderson and Domsch, 1990). Changes in microbial coefficient (MBC/SOC) and $\mathrm{qCO}_{2}$ are useful for assessing the microbial efficiency in the conversion of available $\mathrm{C}$ into microbial biomass, the losses of $\mathrm{C}$ from the soil and the stabilization of organic $\mathrm{C}$ due to its association with mineral fractions of the soil (Liao and Boutton, 2008). Another parameter that characterizes the soil microbiome is the basal soil respiration (SBR) that represents the potential respiratory activity of the microbiome (mainly fungi and bacteria). From the relationship of the three variables (SOC, MBC and SBR) useful indices (metabolic and microbial coefficient) arised to follow the evolution of a soil and its response to different management practices (Zhao et al., 2016, 2017).

In Patagonia there is little knowledge of the effect of type of vegetation, soil characteristics, climate and the grazing on the soil microbiome. Such knowledge would allow a better understanding of the biotic and abiotic factors that modulate the structure and function of the soil microbiome in this ecosystem and, ultimately, the soil quality. Here, we hypothesized that MBC, SBR and the abundance of fungi and total bacteria will correlate positively with rainfall and negatively with grazing intensity, depending the magnitude on the vegetation community. Therefore, our objective was to evaluate the responses of MBC, SBR, the metabolic and microbial coefficient and the abundance of fungi and bacteria when exposed to grazing intensities (moderate vs high) of long-term livestock in an environmental gradient.

\section{Materials and methods}

\subsection{Study sites and characteristics}

The study was realized in an east-west gradient that covered different vegetation communities and climatic conditions in the south of Santa Cruz province, Argentina. These sites correspond to three ecological areas: Mata Negra Thicket (MNT), Dry Magellanic Steppe (DMS) and Humid Magellanic Steppe (HMS), in each ecological area two grazing intensities were contrasted the long term ( $>50$ years) (Moderate and High) (Table 1) (Fig. 1).

\section{1. 1. Climatic characteristics}

The climatic variables of each ecological area related to precipitation and temperature were obtained from meteorological stations. Mean annual temperatures were similar between ecological areas, and ranged from $1.6{ }^{\circ} \mathrm{C}$ (winter in MNT) and $13.7{ }^{\circ} \mathrm{C}$ (summer in MNT) (Fig. 2). Mean annual precipitation in 2016 varied from 125.9 to $178.8 \mathrm{~mm} / \mathrm{yr}$ in MNT and DMS, respectively. In 2017, precipitation ranged from 279.9 to $355.3 \mathrm{~mm} / \mathrm{yr}$ in HMS and DMS, respectively. The year 2017 was colder and with higher rainfall in all ecological areas (Fig. 2).

\section{1. 2. Vegetation characteristics}

The environmental gradient of the sampled sites determines different the plants physiognomy given by the environmental conditions of rainfall and temperature. The characterization of plant cover was carried out in each replicate plot using the points intercept method (Levy and Madden, 1933) along $30 \mathrm{~m}$ long transects and estimated every 10 $\mathrm{cm}$ (300 points per transect) (Table 2). Bare soil cover fluctuated from 31.3 to $3.4 \%$ for MNT with high and HMS with moderate grazing, respectively. Dwarf Shrub and Short grasses coverages had the gradient MNT $<$ DMS $<$ HMS.

The vegetation of the Mata Negra thicket site is dominated by the shrub Mulguraea tridens and associated with short grasses (Poa dusenii, Carex argentina), tussocks (Pappostipa chrysophylla, Festuca gracillima), dwarf-shrubs (Clinopodium darwinii, Nassauvia glomerulosa, Nardophyllum bryoides) and herbs (Acaena poeppigiana). In the dry magellanic steppe, the vegetation is dominated by the Festuca gracillima tussock, associated with short grasses (Poa dusenii, Hordeum comosum, Carex spp., Rytidosperma virescens), dwarf-shrubs (Nardophyllum bryoides, Nassauvia ulicina, Azorella monantha), herbs (Viola maculata, Calceolaria uniflora) and the shrub Berberis microphylla. In the humid magellanic steppe, the vegetation is dominated by tussocks (Festuca pallescens, F. gracillima), and associated with short grasses and herbs (Poa dusenii, Rytidosperma virescens, Bromus setifolius, Agropyron fuegianum, Pappostipa ibari, Acaena poeppigiana, Agrostis flavidula, Phleum alpinum, Perezia recurvata, Carex spp., Calceolaria polyrrhiza), dwarf-shrubs (Senecio laseguei, Empetrum rubrum), and isolated shrub Berberis microphylla.

\subsection{Soil sampling study sites}

This study was established in six sites, defined by the three ecological areas (MNT, DMS and HMS) and two contrasting long-term livestock stocking rates (Moderate and High). In each site, three random replicate plots of $1000 \mathrm{~m}^{2}$ were installed $(\sim 3 \mathrm{~km}$ apart). Soil samples were collected during 2016 and 2017 in the four seasons. In each site, a total of nine composite soil samples (three per plot) were collected from 10 cores ( $5 \mathrm{~cm}$ deep, $5.6 \mathrm{~cm}$ in diameter), previous removal of the surface litter. Soil samples were placed in plastic bags and stored in refrigerated containers until transport to the laboratory. The soils were screened through a $2 \mathrm{~mm}$ mesh, divided into subsamples and stored at $4{ }^{\circ} \mathrm{C}$ for microbial biomass and basal soil respiration analysis and $-80^{\circ} \mathrm{C}$ for quantification of bacterial and fungal soil communities. 
Table 1

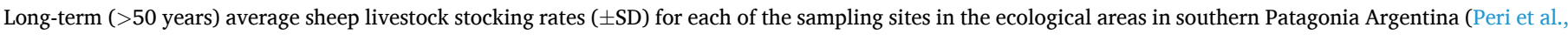
2013).

\begin{tabular}{|c|c|c|c|c|c|c|}
\hline \multirow[t]{2}{*}{ Livestock Land Use } & \multicolumn{2}{|l|}{ MNT } & \multicolumn{2}{|l|}{ DMS } & \multicolumn{2}{|l|}{ HMS } \\
\hline & Moderate & High & Moderate & High & Moderate & High \\
\hline Animal stocking $\left(\mathrm{EO}^{\mathrm{a}} \mathrm{ha}^{-1} \mathrm{año}^{-1}\right)$ & $0.32( \pm 0.06)$ & $1.20( \pm 0.40)$ & $0.13( \pm 0.02)$ & $0.52( \pm 0.22)$ & $0.21( \pm 0.05)$ & $0.62( \pm 0.16)$ \\
\hline
\end{tabular}

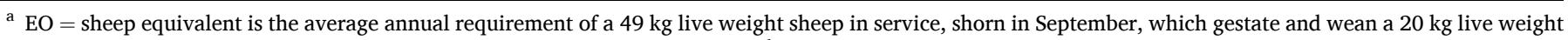
lamb at 100 days of lactation and which has a consumption of $530 \mathrm{~kg}$ DM year ${ }^{-1}$.
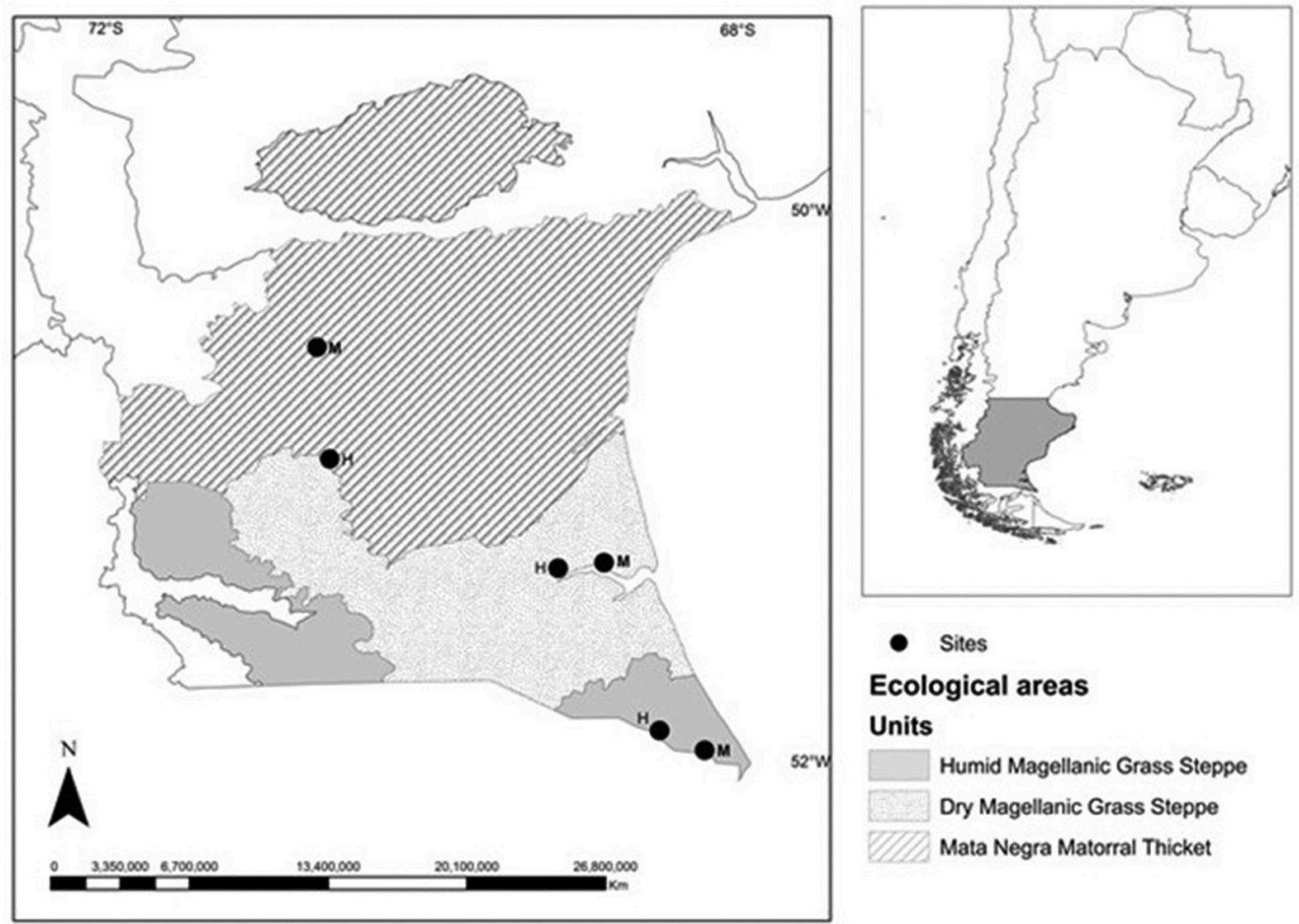

\section{Ecological areas \\ Units}

Humid Magellanic Grass Steppe

Dry Magellanic Grass Steppe

Mata Negra Matorral Thicket

Fig. 1. Location of sampling sites in the environmental gradient with contrasting long-term grazing Moderate (M) and High (H) for each ecological area in Southern Patagonia Argentina.

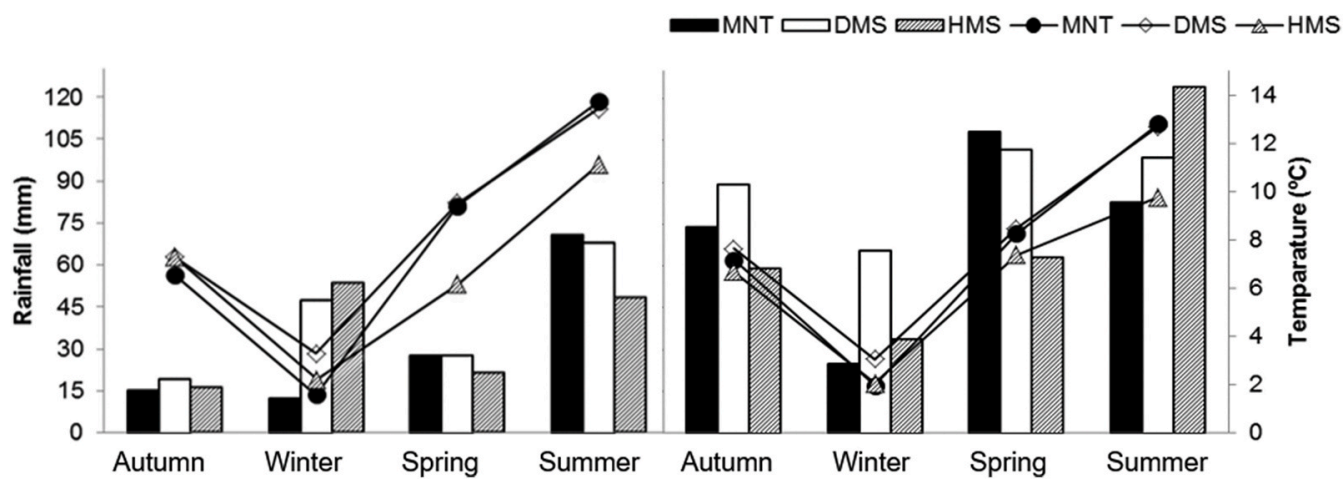

Fig. 2. Climatic variables (Rainfall $(\mathrm{mm})$ and Temperature $\left({ }^{\circ} \mathrm{C}\right)$ ) for seasons and sampling ecological area $(\mathrm{MNT}=$ Mata Negra Thicket, DMS $=$ Dry Magellanic Steppe and HMS = Humid Magellanic Steppe) in the two year (2016 and 2017) for Southern Patagonia Argentina.

\subsection{Soil properties}

The soil samples were finely ground to below $2 \mu \mathrm{m}$ using a tungstencarbide mill. Measurements of soil organic carbon (SOC) concentration were derived from the dry combustion (induction furnace) method. Soil nutrient concentrations were determined as follows: (i) total $\mathrm{N}$ was measured by spectrophotometry; (ii) available P by the Olsen method; and (iii) ammonium acetate-extracted potassium (K) was determined with a plasma emission spectrometer (Shimadzu ICPS-1000 III, Japan). A 1:2.5 mixture of soil:water was used to measure soil $\mathrm{pH}$ using an ion meter. The soil texture was determined through the densimeter method of Bouyoucos and sieving the sand fractions. Soil bulk density was 
Table 2

Description of the landcover of the ecological areas for each of the study sites $(\mathrm{MNT}=$ Mata Negra Thicket, DMS $=$ Dry Magellanic Steppe, and HMS $=$ Humid Magellanic Steppe) evaluated with their respective long-term grazing intensities (Moderate and High) in southern Patagonia. Mean values are shown, different letters indicate significant differences between areas*grazing intensity $(\mathrm{p}<$ 0.05).

\begin{tabular}{|c|c|c|c|c|c|c|}
\hline \multirow{2}{*}{$\begin{array}{l}\text { Soil } \\
\text { Landcover }\end{array}$} & \multicolumn{2}{|l|}{ MNT } & \multicolumn{2}{|l|}{ DMS } & \multicolumn{2}{|l|}{ HMS } \\
\hline & Moderate & High & Moderate & High & Moderate & High \\
\hline Bare soil (\%) & $29.5 a$ & $31.3 \mathrm{a}$ & $21.3 \mathrm{~b}$ & $\begin{array}{l}24.8 \\
\mathrm{ab}\end{array}$ & $3.4 \mathrm{c}$ & $7.2 \mathrm{c}$ \\
\hline Litter (\%) & $6.4 c$ & $5.7 \mathrm{c}$ & $19.3 a$ & $18.8 \mathrm{a}$ & $8.2 \mathrm{c}$ & $\begin{array}{l}11.4 \\
\mathrm{ab}\end{array}$ \\
\hline $\begin{array}{l}\text { Dwarf Shrub } \\
(\%)\end{array}$ & $7.7 \mathrm{c}$ & $9.0 \mathrm{c}$ & $17.9 \mathrm{~b}$ & $18.9 \mathrm{~b}$ & $28.3 a$ & $34.5 \mathrm{a}$ \\
\hline $\begin{array}{l}\text { Short grasses } \\
\text { (\%) }\end{array}$ & $9.8 \mathrm{c}$ & $6.9 c$ & $25.5 a$ & $19.6 \mathrm{~b}$ & $39.7 \mathrm{a}$ & $20.6 \mathrm{~b}$ \\
\hline Tussock (\%) & $9.4 b$ & $11.3 \mathrm{~b}$ & $12.0 \mathrm{~b}$ & $13.6 \mathrm{~b}$ & $16.6 \mathrm{ab}$ & $22.4 \mathrm{a}$ \\
\hline Shrub (\%) & $37.2 \mathrm{a}$ & $35.8 \mathrm{a}$ & $4.0 \mathrm{~b}$ & $4.3 \mathrm{~b}$ & $3.8 \mathrm{~b}$ & $3.9 \mathrm{~b}$ \\
\hline $\begin{array}{l}\text { Species } \\
\text { richness }\end{array}$ & 9 & 9 & 12 & 12 & 16 & 16 \\
\hline
\end{tabular}

estimated using the cylindrical core method $(n=3)$ by collecting a known volume of soil using a metal tube pressed into the soil (intact core), and determining the weight after drying.

\subsection{Soil microbiology}

\section{4. 1. Microbial biomass carbon and respiration}

Microbial biomass carbon (MBC) was estimated using the "fumigation-extraction" method (Vance et al., 1987). MBC was calculated as: (OCf - OCnf)/kEC; where: OCf $=$ organic carbon extracted from fumigated samples; OCnf $=$ Carbon extracted from non-fumigated samples; and $\mathrm{kEC}=$ fumigation efficiency constant $=0.45$ (Joergensen, 1996).

Soil basal respiration (SBR) was measured according to a standardized method under optimal conditions of humidity and temperature (Robertson et al., 1999). The $\mathrm{CO}_{2}$ evolution from soil samples was determined at 1, 7, 14, 21 days, and SBR was calculated from the difference with blanks without soil.

\section{4. 2. DNA extraction and $q P C R$ for soil bacterial and fungal the communities quantification}

Total DNA was extracted from $0.25 \mathrm{~g}$ soil samples using the PowerSoil DNA isolation kit (MoBio Laboratories) following the manufacturer's instructions. DNA was quantified using a NanoDrop 1000 spectrophotometer (NanoDrop Technologies, Montchanin, USA), and checked by agarose gel electrophoresis and SYBRSafe (Invitrogen) staining. The abundance quantification of bacterial and fungal communities in soil samples was carried out in an Mx3000P qPCR system (Agilent Technologies) using the FastStart Universal SYBR Green Master (Rox) kit. For bacterial communities, a fragment of the 16S rRNA gene was amplified using the primers pair Eub338/Eub518(Fierer et al., 2005) at a final concentration of $0.3 \mathrm{nM}$ and annealing at $53{ }^{\circ} \mathrm{C}$. For fungal communities, a fragment of the 18S rRNA gene was amplified using FR1/FF390 primers (Prévost-Bouré et al., 2011) at the final concentration of $0.66 \mathrm{nM}$ and annealing at $50{ }^{\circ} \mathrm{C}$. Standard curves were made by decimal dilutions of genomic DNA of Bradyrhizobium diazoefficiens USDA $110\left(1.1 \times 10^{3}\right.$ to $1.1 \times 10^{7} 16 \mathrm{~S}$ rDNA copies $)$ or a linearized plasmid containing the amplified target sequence of Trichoderma harzianum $\left(7.93 \times 10^{4}\right.$ to $7.93 \times 10^{8} 18 \mathrm{~S}$ rDNA copies) for bacteria and fungi, respectively. Soil DNA samples, standard curves, and negative controls were analyzed in triplicate in each PCR microplate. After amplification reactions, melting curves and gel electrophoresis analyses were performed to confirm that the amplified products had the appropriate size. The qPCR efficiencies were $\%\left(r^{2}=102\right)$ for bacteria and $\%\left(r^{2}=97\right)$ for fungi.

\section{4. 3. Metabolic and microbial indexes}

The microbial metabolic coefficient $\left(\mathrm{qCO}_{2}\right)$ was determined by the ratio between the $\mathrm{C}-\mathrm{CO}_{2}$ produced by basal soil respiration and the $\mathrm{MBC}$, and microbial ratio ( $\mathrm{qM}$ ) was determined by the $\mathrm{MBC} / \mathrm{SOC}$ ratio that reflects the contribution of microbial biomass to SOC (Anderson and Domsch, 1993).

\subsection{Statistical analysis}

Statistical analyses were performed using INFOSTAT software (Di Rienzo et al., 2013). Vegetation and soil variables were analyzed with a two-way analysis of variance (ANOVA). The MBC data were analyzed with multifactorial ANOVA, with the factors being the ecological areas (MNT, DMS and HMS), the grazing intensities (Moderate and High), the seasons (Autumn, Winter, Spring, and Summer) and the years of measurement (2016 and 2017). The SBR, $\mathrm{qCO}_{2}$, and $\mathrm{qM}$ data were performed by a two-way analysis of variance (ANOVA), using ecological areas (MNT, DMS and HMS) and grazing intentities (Moderate and High) as factors. For statistical analysis of bacterial and fungi gene copies, values were transformed to $\log _{10}$ of the number gene copies $\mathrm{g}^{-1}$ soil dry and an analysis of variance (ANOVA) was performed in three-way, (i) using the ecological areas (MNT, DMS and HMS), (ii) grazing intensities (Moderate and High) and (iii) the years (2016 and 2017) of measurement as factors. Significant differences between means were separated by Tukey's test with a significance level of $p<0.05$. The Pearson's correlation indices obtained from paired analyses for soil, climate, and vegetation for $\mathrm{MBC}, \mathrm{SBR}, \mathrm{qCO}_{2}, \mathrm{qM}$, fungi, bacteria, and the fungi/bacteria ratio were determined. Simple linear regressions were performed to identify and select the variables that explain the variance of MBC and SRB. Simple linear regressions were performed to identify and select the variables that explain variations of MBC and SRB. Previously, a collinearity test between explanatory variables was performed by using the tolerance and variance inflation factor (VIF). The Akaike Information Criterion (AIC) was used to compare and select the best regression models.

\section{Results}

\subsection{Soil properties}

Soil physicochemical parameters varied among the ecological areas and animal grazing (Table 3). Soil characteristics had $\mathrm{pH}$ ranges between 5 and 6 depending on the sites, soil textures were predominantly sandy and sandy loam, and with organic carbon values between 1.27 and $3.83 \%$ for MNT and HMS, respectively.

\subsection{Microbial biomass carbon and abundance of fungi and bacteria}

Results showed that MBC varied significantly $(p<0.05)$ among the ecological areas, grazing intensity and seasons (Table 4). Soil MBC had the gradient of MNT $<$ DMS $<$ HMS. The obtained results determined that sheep grazing intensity significantly affected the MBC, with lower values in the sites with high grazing intensity ( $412 \mu \mathrm{g} \mathrm{C} \mathrm{g-1} \mathrm{dry} \mathrm{soil)} \mathrm{and}$ the highest in sites with moderate grazing intensity (512 $\mu \mathrm{g} \mathrm{C} \mathrm{g-1} \mathrm{dry}$ soil). Considering that microbial biomass carbon is one of the labile and active fractions of organic matter present in the soil, we found that MBC varied between seasons (Autumn, Winter, Spring, and Summer), autumn and spring contrasted the lowest and highest values, respectively. In addition, the MBC presented an inter-annual fluctuation that was observed between the sampling years (Table 4).

Also, total fungi abundance (18S rDNA gene copies) and the fungi/ bacteria ratio $(18 \mathrm{~S} / 16 \mathrm{~S}$ rDNA) varied significantly $(\mathrm{p}<0.05)$ in the different ecological areas. The total soil fungi values had the gradient of HMS $>$ DMS $>$ MNT with statistical significance $(\mathrm{p}<0.05)$. Regarding the years of sampling, there was a greater abundance of bacteria in 2016 compared to 2017, contrastingly, soil samples obtained in 2017 had a 
Table 3

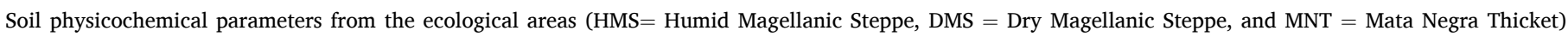

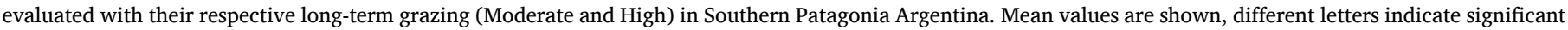
differences between areas*grazing intensity $(\mathrm{p}<0.05)$.

\begin{tabular}{|c|c|c|c|c|c|c|}
\hline \multirow[t]{2}{*}{ Soil parameter ${ }^{\mathrm{a}}$} & \multicolumn{2}{|l|}{ MNT } & \multicolumn{2}{|l|}{ DMS } & \multicolumn{2}{|l|}{ HMS } \\
\hline & Moderate & High & Moderate & High & Moderate & High \\
\hline Textural class & Sandy Loam & Sandy Loam & Sandy & Sandy & Sandy Loam & Sandy \\
\hline Bulk density $\left(\mathrm{g} \mathrm{cm}^{-3}\right)$ & $1.15 b c$ & $1.21 \mathrm{c}$ & $0.96 \mathrm{ab}$ & $1.07 \mathrm{bc}$ & $0.80 \mathrm{a}$ & $0.82 \mathrm{a}$ \\
\hline $\mathrm{pH}$ & $5.98 \mathrm{~b}$ & $5.60 \mathrm{ab}$ & $5.60 \mathrm{ab}$ & $5.57 \mathrm{ab}$ & $5.20 \mathrm{a}$ & $5.16 \mathrm{a}$ \\
\hline SOC (\%) & $1.27 \mathrm{a}$ & $1.67 \mathrm{ab}$ & $2.67 b c$ & $1.71 \mathrm{ab}$ & $3.03 \mathrm{c}$ & $3.83 \mathrm{c}$ \\
\hline Nt $(\%)$ & $0.11 \mathrm{a}$ & $0.13 \mathrm{ab}$ & $0.18 \mathrm{abc}$ & $0.13 \mathrm{ab}$ & $0.26 c$ & $0.24 b c$ \\
\hline $\mathrm{P}$ available (ppm) & $25.12 b$ & $25.27 b$ & $12.27 \mathrm{a}$ & $12.40 \mathrm{a}$ & $16.07 \mathrm{ab}$ & $18.23 \mathrm{ab}$ \\
\hline $\mathrm{K}(\mathrm{meq} / 100 \mathrm{~g})$ & $0.41 c$ & $0.22 \mathrm{ab}$ & $0.78 \mathrm{~d}$ & $0.16 \mathrm{a}$ & $0.32 \mathrm{bc}$ & $0.21 \mathrm{ab}$ \\
\hline $\mathrm{C}: \mathrm{N}$ & $11.50 \mathrm{a}$ & $12.80 \mathrm{a}$ & $14.80 \mathrm{a}$ & $13.10 \mathrm{a}$ & $11.60 \mathrm{a}$ & $15.90 \mathrm{a}$ \\
\hline
\end{tabular}

a SOC: Soil Organic Carbon; Nt: Total Nitrogen.

Table 4

Statistics summary of the MBC ( $\mu \mathrm{g} \mathrm{C} \mathrm{g}^{-1}$ dry soil), $16 \mathrm{~S}$ rDNA ( ${ }^{\circ}$ gene copies $\mathrm{g}^{-1}$ dry soil), 18S rDNA ( $\mathrm{N}^{\circ}$ gene copies $\mathrm{g}^{-1}$ dry soil) and the relationship between both rDNA genes (18S/16S, dimensionless) in the different ecological areas (MNT, DMS, and HMS) with grazing intensities (Moderate and High) during two years of continuous sampling (2016 and 2017). With seasonal measurements for MBC (Autumn, Winter, Spring, and Summer) in the grasslands of South Patagonia Argentina. Mean values are shown. Different letters indicate significant differences ( $\mathrm{p}<0.05)$.

\begin{tabular}{|c|c|c|c|c|}
\hline Variation sources & MBC & 16S rDNA & 18S rDNA & $\begin{array}{l}18 \mathrm{~S} / 16 \mathrm{~S} \\
\text { rDNA }\end{array}$ \\
\hline Areas & $\begin{array}{l}\mathrm{F}=83.48 \\
\mathrm{p}=<0.0001\end{array}$ & $\begin{array}{l}\mathrm{F}=2.89 \\
\mathrm{p}=0.075\end{array}$ & $\begin{array}{l}F=24.76 \\
p=<0.0001\end{array}$ & $\begin{array}{l}\mathrm{F}=4.17 \\
\mathrm{p}=0.028\end{array}$ \\
\hline MNT & 308 a & $6.00 \mathrm{E}+09 \mathrm{a}$ & $3.00 \mathrm{E}+06 \mathrm{a}$ & $0.05 \mathrm{a}$ \\
\hline DMS & $501 \mathrm{~b}$ & $9.00 \mathrm{E}+09 \mathrm{a}$ & $5.00 \mathrm{E}+06 \mathrm{~b}$ & $0.07 \mathrm{ab}$ \\
\hline HMS & $577 \mathrm{c}$ & $8.00 \mathrm{E}+09 \mathrm{a}$ & $7.00 \mathrm{E}+06 \mathrm{~b}$ & $0.12 \mathrm{~b}$ \\
\hline $\begin{array}{l}\text { Grazing } \\
\text { intensity }\end{array}$ & $\begin{array}{l}F=39.68 \\
p=<0.0001\end{array}$ & $\begin{array}{l}\mathrm{F}=1.69 \\
\mathrm{p}=0.206\end{array}$ & $\begin{array}{l}\mathrm{F}=1.43 \\
\mathrm{p}=0.243\end{array}$ & $\begin{array}{l}\mathrm{F}=0.81 \\
\mathrm{p}=0.376\end{array}$ \\
\hline Moderate & 512 a & $8.00 \mathrm{E}+09 \mathrm{a}$ & $5.00 \mathrm{E}+06 \mathrm{a}$ & $0.07 \mathrm{a}$ \\
\hline High & $412 \mathrm{~b}$ & $7.00 \mathrm{E}+09 \mathrm{a}$ & $5.00 \mathrm{E}+06 \mathrm{a}$ & $0.09 \mathrm{a}$ \\
\hline Stations & \multicolumn{4}{|c|}{$\mathrm{F}=63.19 ; \mathrm{p}=<0.0001$} \\
\hline Autumn & \multicolumn{4}{|c|}{$409 \mathrm{a}$} \\
\hline Winter & \multicolumn{4}{|l|}{$473 \mathrm{~b}$} \\
\hline Spring & \multicolumn{4}{|l|}{$505 \mathrm{c}$} \\
\hline Summer & \multicolumn{4}{|l|}{$461 \mathrm{~b}$} \\
\hline Year & $\begin{array}{l}F=23.71 \\
p=<0.0001\end{array}$ & $\begin{array}{l}F=10.07 \\
p=0.004\end{array}$ & $\begin{array}{l}\mathrm{F}=23.82 \\
\mathrm{p}=0.0001\end{array}$ & $\begin{array}{l}F=14.65 \\
p=0.0008\end{array}$ \\
\hline $1(2016)$ & $474 \mathrm{a}$ & $9.00 \mathrm{E}+09 \mathrm{~b}$ & $4.00 \mathrm{E}+06 \mathrm{a}$ & $0.04 \mathrm{a}$ \\
\hline $2(2017)$ & $450 \mathrm{~b}$ & $7.00 \mathrm{E}+09 \mathrm{a}$ & $6.00 \mathrm{E}+06 \mathrm{~b}$ & $0.12 \mathrm{~b}$ \\
\hline \multicolumn{5}{|l|}{ Interactions } \\
\hline Areas*Grazing & $\begin{array}{l}\mathrm{F}=14.42 \\
\mathrm{p}=< \\
0.0001\end{array}$ & $\begin{array}{l}F=1.10 \\
p=0.349\end{array}$ & $\begin{array}{l}F=7.18 \\
p=0.003\end{array}$ & $\begin{array}{l}F=3.07 \\
p=0.065\end{array}$ \\
\hline Areas*Stations & \multicolumn{4}{|c|}{$\mathrm{F}=10.89 ; \mathrm{p}=<0.0001$} \\
\hline Areas*Years & $\begin{array}{l}F=47.77 \\
p=< \\
0.0001\end{array}$ & $\begin{array}{l}F=4.46 \\
p=0.022\end{array}$ & $\begin{array}{l}F=0.70 \\
p=0.504\end{array}$ & $\begin{array}{l}F=2.06 \\
p=0.148\end{array}$ \\
\hline
\end{tabular}

greater abundance of fungi compared to the samples obtained in 2016, in both cases there were statistical differences.

\subsection{Interactions between factors on the response of $M B C$ and total soil fungi and bacteria}

The interaction between ecological areas and grazing intensity for MBC showed that while in MNT both animal grazing intensities did not presented statistical differences, in HMS and DMS with moderate grazing intensity, presented higher values of MBC than in the sites with high grazing intensity. We also observed that in the DMS, the high grazing intensity generated a more significant decrease in $\mathrm{MBC}$ compared to the HMS (Fig. 3 A). The ecological areas*seasons for the MBC showed significant statistical differences ( $p<0.05$ ) (Fig. 3 B). The ecological area MNT in all seasons of the year presented the lowest MBC values (225.3 $\mu \mathrm{g} \mathrm{MBC} \mathrm{g}^{-1}$ soil) statistically differentiated from HMS in the four seasons of the year. The DMS had intermediate values in the seasons without statistical difference from HMS and MNT.

The interaction between ecological areas and years for the number bacterias (16S rDNA) and fungi (18S rDNA), determined a greater abundance of bacteria than fungi in soils. Total soil bacteria followed the same gradient in year 1 (2016), and in year 2 (2017), the highest number was observed in the DMS (Fig. 4A). The values of total soil fungi had the gradient of HMS $>$ DMS $>$ MNT in both sampling years (Fig. 4B).

The variation interannual MBC interacted with the ecological areas, we observed that MNT and DMS, had higher values in year 2016 compared to year 2017 of measurement. However, that response was inverse for the HMS, where year 2016 had a significantly lower value (555 $\mu_{\mathrm{g} \mathrm{C} \mathrm{g}}{ }^{-1}$ dry soil) than year 2017 (599 $\mu \mathrm{g} \mathrm{C} \mathrm{g}^{-1}$ dry soil) (Fig. $5 \mathrm{~A}$ ). Also, the $18 \mathrm{~S} / 16 \mathrm{~S}$ rDNA (fungi/bacteria) ratio of the soils showed differences between those in different ecological areas and between years ( $p<0.05$ ). The ratios were lower in year 2016 compared to year 2017 in all ecological areas. It was observed that in the MNT it had the lowest relationship in year 2016 and that the HMS in year 2017 presented the highest value (Fig. 5 B).

\subsection{Soil biological respiration, metabolic coefficient and microbial coefficient}

$\mathrm{SRB}, \mathrm{qCO}_{2}$, and $\mathrm{qM}$ differed significantly $(\mathrm{p}<0.05)$ between the different ecological areas evaluated. SRB was higher in HMS compared to DMS and MNT. The $\mathrm{qCO}_{2}$ was lower in the DMS compared to the other observed ecological areas, HMS had the highest value. Further, we observed that qM had the lowest values for HMS and the highest values for MNT. The qM varied significantly $(\mathrm{p}<0.05)$ depending on the grazing intensity. The high grazing intensity presented a lower value than the moderate grazing intensity. Likewise, interactions between the factors were detected (Table 5).

\subsection{Interactions between factors in the response of $S B R, q \mathrm{CO}_{2}$, and $q M$}

The interaction between ecological areas and animal grazing for SBR ( $p<0.05$ ) determined that while in HMS high animal grazing intensity presented the highest values during the incubation period $(689.9 \mathrm{mg}$ C- $-\mathrm{CO}_{2} \mathrm{Kg}^{-1}$ dry soil at day 21) followed by moderate grazing intensity (532.9 mg C- $-\mathrm{CO}_{2} \mathrm{Kg}^{-1}$ dry soil at day 21 ), DMS presented an inverse response (moderate $>$ high) (Fig. 6). In MNT after day 7 of incubation, SBR values in both animals exceeded the high DMS grazing.

The interaction of ecological areas*grazing for $\mathrm{qCO}_{2}$ showed differences $(\mathrm{p}<0.05)$ (Table 5). While in the DMS both grazing intensity (High and Moderate) had the lowest values without significant differences ( 0.09 and $0.10 \mu \mathrm{g} \mathrm{C}-\mathrm{CO}_{2} \mathrm{mg}^{-1} \mathrm{MBC}$ day $^{-1}$ ), the highest values were obtained in the HMS for high grazing intensity $\left(0.19 \mu \mathrm{g}-\mathrm{CO}_{2}\right.$ $\mathrm{mg}^{-1} \mathrm{MBC}$ day $^{-1}$ ) (Fig. $7 \mathrm{~A}$ ). The ecological areas* grazing for the soil $\mathrm{qM}$, determined that in the HMS with high grazing had the lowest value 

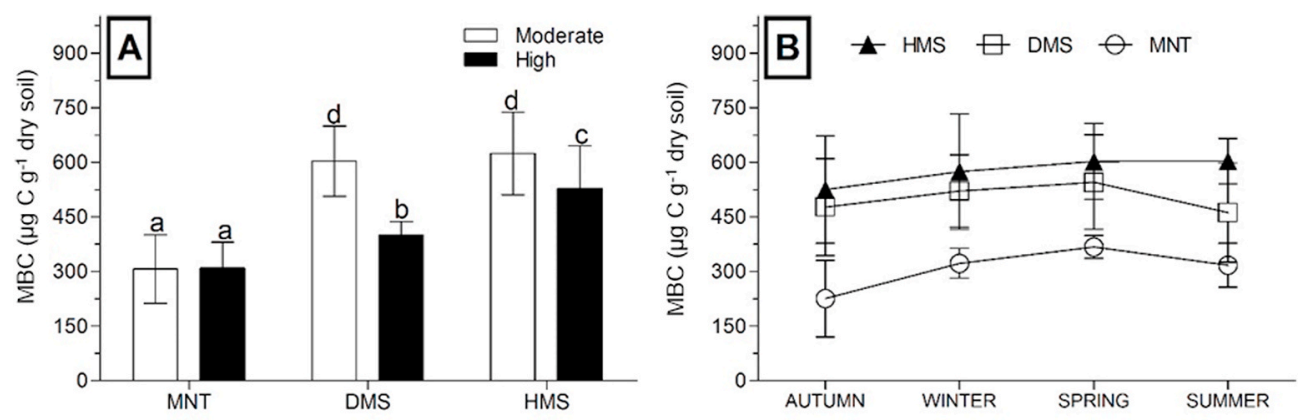

Fig. 3. Mean values and standard deviation of MBC ( $\mu \mathrm{g} \mathrm{C} \mathrm{g}{ }^{-1}$ dry soil) as a function of the interactions between ecological areas*grazing intensity (A) and seasons*ecological areas (B) for southern Patagonia Argentina. HMS $=$ Humid Magellanic Steppe, DMS = Dry Magellanic Steppe, and MNT $=$ Mata Negra Thicket. Different letters indicate significant differences $(\mathrm{p}<0.05)$.
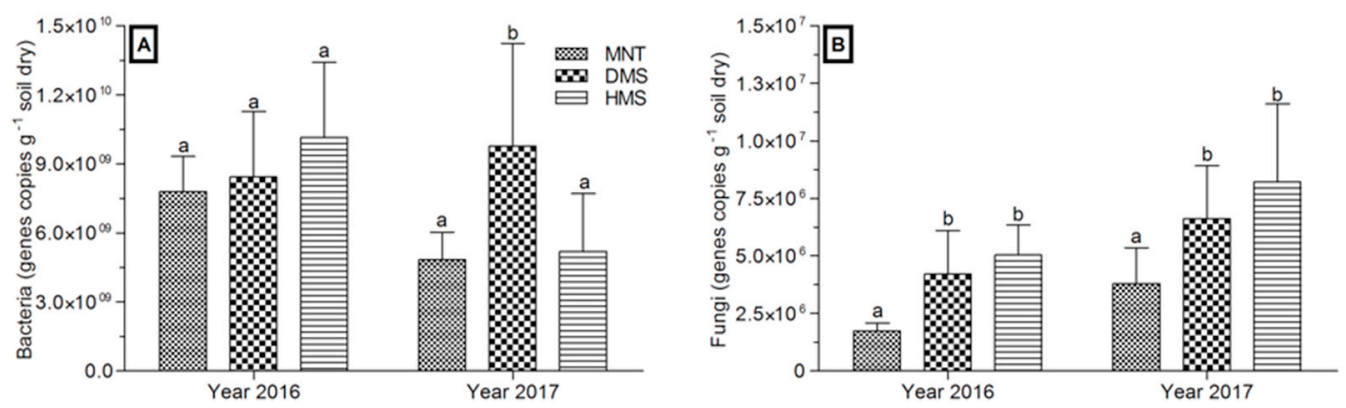

Fig. 4. Mean values and standard deviation of the $\mathrm{N}^{\circ}$ genes copies $\mathrm{g}^{-1}$ dry soil of $16 \mathrm{~S}$ rDNA (total bacteria) and $18 \mathrm{~S}$ rDNA (total fungi) as a function of the interaction between years and ecological areas (HMS = Humid Magellanic Steppe, DMS = Dry Magellanic Steppe, and MNT = Mata Negra Thicket) for southern Patagonia Argentina. Different letters indicate significant differences $(\mathrm{p}<0.05)$.
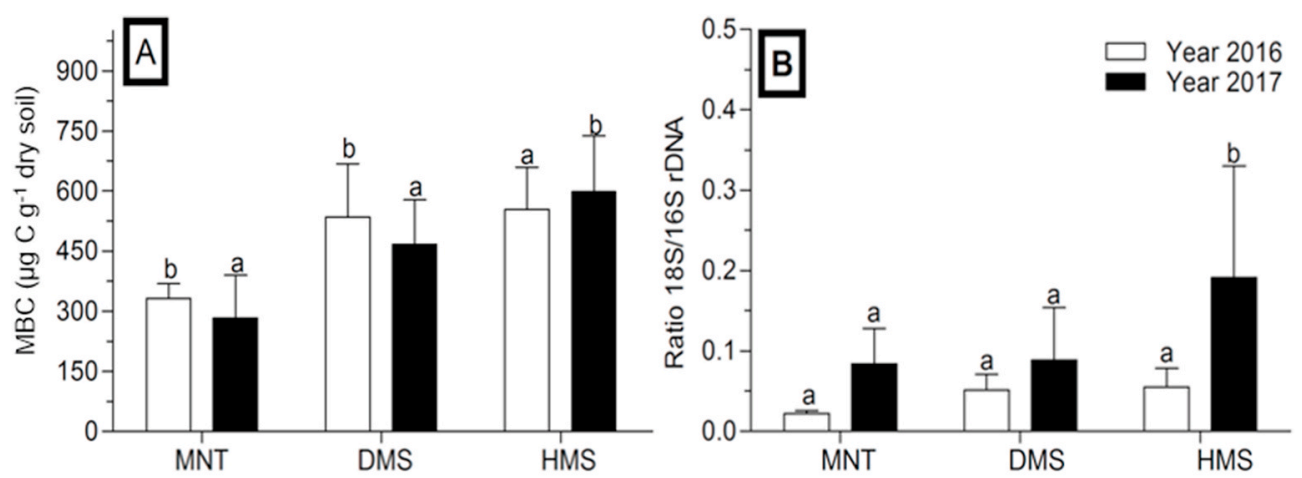

Fig. 5. Mean values and standard deviation of the MBC ( $\mu \mathrm{g}$ C g-1 dry soil) as a function of the interactions between ecological areas*year (A) and gene copies ratio soil 18S/16S rDNA (fungi/bacteria) of ecological areas*years (B) in southern Patagonia Argentina. HMS= Humid Magellanic Steppe, DMS = Dry Magellanic Steppe, and MMN $=$ Mata Negra Thicket. Different letters indicate significant differences $(\mathrm{p}<0.05)$.

(1.45\%), MNT with the moderate grazing presented the highest value (2.99\%), and the intermediate values were given by the DMS (Fig. 7 B).

\subsection{Correlation of microbiological variables with environmental variables, soils, and vegetation}

The microbiological variables evaluated presented significant correlations $(\mathrm{p}<0.05)$ with the soil, vegetation, and environmental variables and between the same variables measured. Soil organic carbon, total $\mathrm{N}$, mean annual precipitation, and mean annual temperature had a positive correlation with $\mathrm{MBC}, \mathrm{SBR}, \mathrm{qCO}_{2}$, and total soil fungi abundance. However, $\mathrm{P}$, soil bulk density and bare soil cover had a negative correlation with the variables (Table 6). Soil organic carbon explained $87 \%$ of the observed variability in soil respiration and $54 \%$ for the variability in MBC $(\mathrm{p}<0.05)$. We obtained a positive linear relationship with both variables (Fig. $8 \mathrm{AB}$ ). SBR was linearly and positively related to MBC, which was explained by $54 \%$ for the soils of the Southern Patagonia grasslands (Fig. 8 C).

\section{Discussion}

The present study shows the first results on soil microbiology in southern sites of the Argentine Patagonia. We showed that biotic and abiotic factors such as, climate through temperature and precipitation, plant communities and soil characteristics modulate the microbial structure and function in each of the ecological areas. On the other hand, high grazing intensity decreased the $\mathrm{MBC}$ and $\mathrm{qM}$, however the magnitude of the response depended on the ecological areas. Further, grazing intensity indirectly affected the microbial soil community through its impacts on plants, which limits the substrates (plant litter 
Table 5

Statistics summary of the SBR (mg C- $\mathrm{CO}_{2} \mathrm{Kg}^{-1}$ dry soil day $\left.{ }^{-1}\right), \mathrm{qCO}_{2}\left(\mu \mathrm{gC}-\mathrm{CO}_{2}\right.$ $\mathrm{mg}^{-1} \mathrm{MBC}$ day $^{-1}$ ) and qM (\%) in the different ecological areas (HMS $=$ Humid Magellanic Steppe, DMS = Dry Magellanic Steppe, and MNT = Mata Negra Thicket) and long-term ( $>50$ years) grazing intensity (Moderate and High) in the Southern Patagonia Argentina. Different letters indicate significant differences (p $<0.05)$.

\begin{tabular}{llll}
\hline Variation sources & $\mathrm{SBR}$ & $\mathrm{qCO}_{2}$ & $\mathrm{qM}$ \\
\hline Areas & $\mathrm{F}=54.92$ & $\mathrm{~F}=8.83$ & $\mathrm{~F}=44.97$ \\
& $\mathrm{p}=<0.0001$ & $\mathrm{p}=0.0005$ & $\mathrm{p}=<0.0001$ \\
MNT & $37 \mathrm{a}$ & $0.13 \mathrm{~b}$ & $2.43 \mathrm{~b}$ \\
DMS & $45 \mathrm{a}$ & $0.09 \mathrm{a}$ & $2.34 \mathrm{~b}$ \\
HMS & $88 \mathrm{~b}$ & $0.16 \mathrm{~b}$ & $1.75 \mathrm{a}$ \\
Grazing & $\mathrm{F}=0.42$ & $\mathrm{~F}=0.50$ & $\mathrm{~F}=10.92$ \\
& $\mathrm{p}=0.519$ & $\mathrm{p}=0.483$ & $\mathrm{p}=<0.0001$ \\
Moderate & $58 \mathrm{a}$ & $0.12 \mathrm{a}$ & $2.50 \mathrm{~b}$ \\
High & $55 \mathrm{a}$ & $0.13 \mathrm{a}$ & $1.84 \mathrm{a}$ \\
\hline Interactions & & & \\
Areas*Grazing & $\mathrm{F}=7.39$ & $\mathrm{~F}=9.46$ & $\mathrm{~F}=15.58$ \\
& $\mathrm{p}=0.0016$ & $\mathrm{p}=0.0274$ & $\mathrm{p}=0.0005$ \\
\hline
\end{tabular}

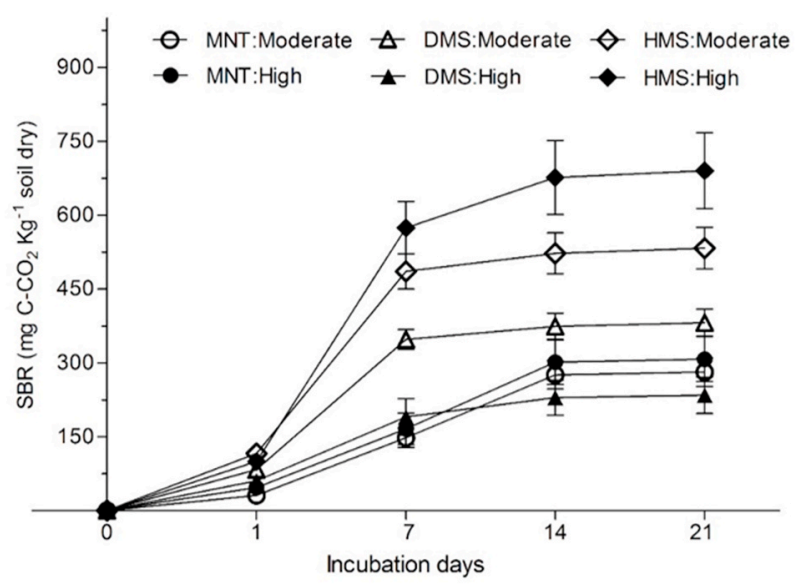

Fig. 6. Mean values and standard deviation of the SBR (mg C- $\mathrm{CO}_{2} \mathrm{Kg}^{-1}$ dry soil) at the sites (HMS:High = Humid Magellanic Steppes High, DMS:High = Dry Magellanic Steppes High, MNT:HIGH = Mata Negra Thicket High, HMS: Moderate $=$ Humid Magellanic Steppes Moderate, DMS: Moderate = Dry Magellanic Steppes Moderate and MNT: Moderate = Mata Negra Thicket Moderate) depending on the days of incubation for the southern Patagonia Argentina.

and rhizodeposition) that serve for microbial growth. Finally, there was a seasonal and interannual dynamic in the MBC and the bacteria and fungal communities, which were attributed to temperature and mainly to precipitation, these climatic factors stimulating greater growth and activity in plants, indirectly providing improvements on the soil microbiome. The results indicate that the effect of grazing intensity in soil microbial communities depends largely on the particular characteristics of each ecological area defined in the environmental gradient by biotic and abiotic factors.

\subsection{Microbial biomass carbon}

The ecological areas evaluated had variation in MBC related to climatic conditions, vegetation and soil. Annual precipitation is the variable that determinates the net primary productivity and as a consequence the soil C input (Jobbágy et al., 2002). This was corroborated with greater ground cover at the HMS site which is described as a wetter site. The soil variable that affected the MBC for our study was the soil organic carbon, which had the gradient in the ecological area (HMS $>$ DMS $>$ MNT) which coincided with a greater vegetation cover and the rainfall. Confirmed in our study with the positive linear relationship between soil organic carbon and MBC (Fig. 8 A). This same positive relationship was reported for grassland and forest soils in several climatic regions (Franzluebbers et al., 2001; Dube et al., 2009; Richter et al., 2018). Therefore, it has been shown that soil organic carbon is one of the main drivers that benefits soil microbial communities in the ecological areas of the Argentine Southern Patagonia.

Our results have shown a decrease in soil microbial biomass in areas with high grazing intensity, which coincide with other grassland studies (Holt, 1997; Zhou et al., 2017). Peri (2011) reported that the carbon content in the grasslands decreased from $130 \mathrm{Mg} \mathrm{C}^{-1}$ with low grazing ( 0.10 sheep ha ${ }^{-1}$ year $^{-1}$ ) to $50 \mathrm{Mg} \mathrm{C} \mathrm{ha}^{-1}$ with high grazing ( 0.70 sheep ha $^{-1}$ year $^{-1}$ ), mainly due to a decrease in vegetation cover and the loss of soil carbon as a result of erosion due to strong winds. However, there are studies that show an increase in MBC and others that show no changes in microbial biomass (Hamilton and Frank, 2001; Liu et al., 2012; Lin et al., 2017). Grazing intensity in grasslands can indirectly affect $\mathrm{MBC}$ through changes in the availability of substrate for microorganisms (yawning, urine and plant material) and changes in the quantity and quality of root exudates and plant litter (Bardgett et al., 1998; Peri et al., 2016a, 2018). Also, grazing intensity leads to a selectivity on the part of livestock that changes the structure of the plant community, resulting in differences in the quality of carbon reserves entering soil (Augustine and McNaughton, 1998). In our sites, high grazing intensity tends to increase the percentage of bare soil (Table 2), which would decrease the carbon entering the soil and soil moisture, resulting in an increased evaporation modifying the microbial biomass (Northup et al., 1999). Supporting this, we found a negative relationship between bare soil cover and MBC (Table 6). The grazing intensity (moderate vs high) in each ecological area had different responses in the MBC in their interactions (ecological area*grazing intensity), given by the characteristics of each site and its resilience. While in the MNT area the MBC behaved interchangeably to the grazing, the magnitude of the
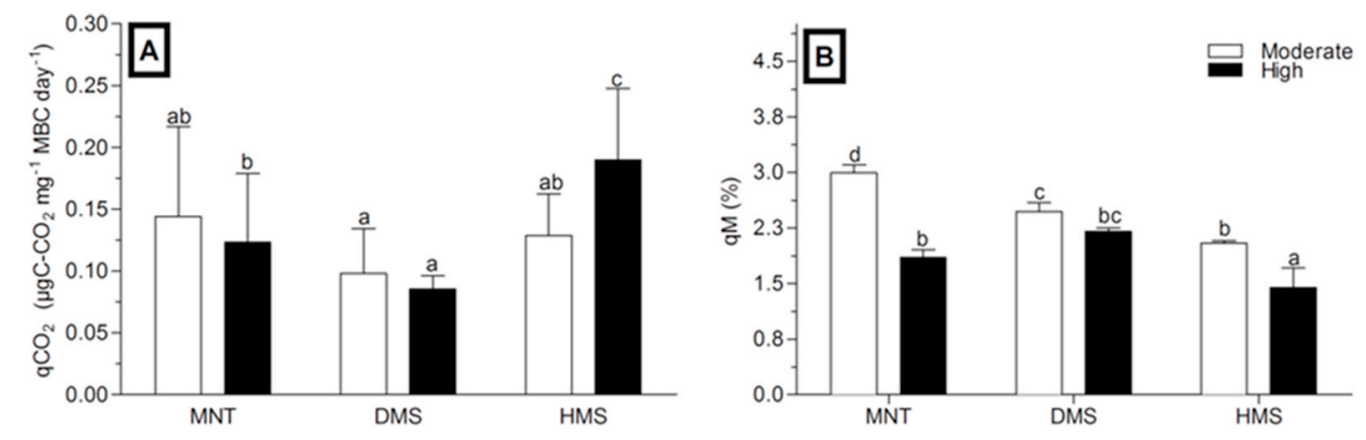

Fig. 7. Mean values and standard deviation of the (A) $\mathrm{qCO}_{2}\left(\mu \mathrm{gC}-\mathrm{CO}_{2} \mathrm{mg}^{-1} \mathrm{MBC}\right.$ day $\left.{ }^{-1}\right)$ and (B) $\mathrm{qM}(\%)$ as a function of the interaction between ecological areas*grazing intensity for Southern Patagonia Argentina. (HMS $=$ Humid Magellanic Steppe, DMS = Dry Magellanic Steppe, and MNT $=$ Mata Negra Thicket) and grazing intensities (High and Moderate). Different letters indicate significant differences $(\mathrm{p}<0.05)$. 
Table 6

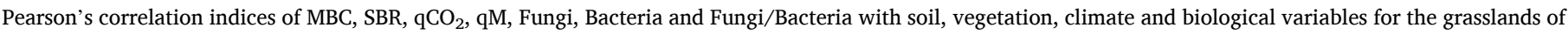
South Patagonia Argentina. (*) Significance with a $\mathrm{p}<0.05$.

\begin{tabular}{|c|c|c|c|c|c|c|c|}
\hline Variables & MBC & SBR & $\mathrm{qCO}_{2}$ & qM & Fungi & Bacteria & Fungi/Bacteria \\
\hline SOC & $0.73^{*}$ & $0.93^{*}$ & $0.53^{*}$ & $-0.66^{*}$ & $0.59 *$ & 0.19 & 0.35 \\
\hline Total Nitrogen & $0.72 *$ & $0.82^{*}$ & 0.30 & $-0.51 *$ & $0.50 *$ & 0.09 & 0.33 \\
\hline $\mathrm{P}$ & -0.52 & -0.24 & 0.35 & 0.13 & $-0.58 *$ & -0.45 & -0.23 \\
\hline $\mathrm{K}$ & $0.58^{*}$ & 0.05 & -0.12 & $0.50 *$ & 0.11 & 0.40 & -0.19 \\
\hline $\mathrm{pH}$ & -0.40 & $-0.58^{*}$ & -0.35 & $0.69^{*}$ & $-0.48^{*}$ & 0.21 & $-0.46^{*}$ \\
\hline Bulk Density & $-0.79 *$ & $-0.89 *$ & -0.35 & 0.45 & $-0.57^{*}$ & -0.25 & -0.40 \\
\hline MAT & $0.66^{*}$ & 0.40 & -0.25 & -0.20 & $0.59^{*}$ & 0.46 & 0.21 \\
\hline MAP & $0.73^{*}$ & $0.74 *$ & 0.14 & $-0.55^{*}$ & $0.75^{*}$ & 0.32 & $0.46^{*}$ \\
\hline Bare soil & $-0.69^{*}$ & $-0.85^{*}$ & -0.35 & $0.51 *$ & $-0.67^{*}$ & -0.17 & $-0.50^{*}$ \\
\hline $\mathrm{MBC}$ & & $0.75 *$ & 0.17 & -0.12 & $0.56^{*}$ & $0.51 *$ & 0.17 \\
\hline SBR & & & 0.62 * & $-0.55^{*}$ & $0.56^{*}$ & 0.19 & 0.37 \\
\hline $\mathrm{qCO}_{2}$ & & & & -0.38 & 0.14 & -0.24 & 0.27 \\
\hline $\mathrm{qM}$ & & & & & -0.30 & 0.09 & -0.31 \\
\hline
\end{tabular}
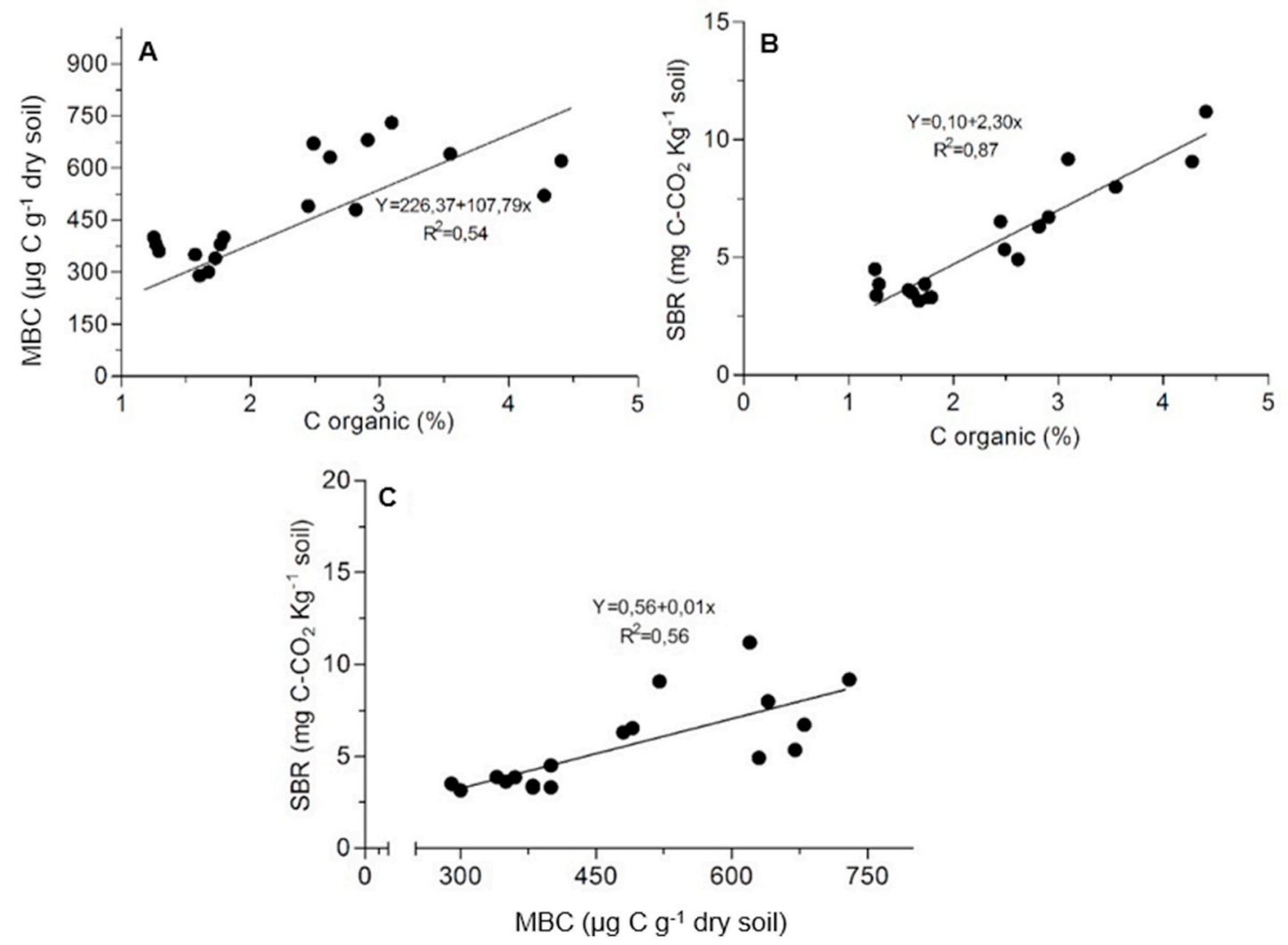

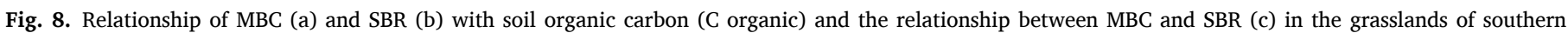
Patagonia Argentina. Model with the lower Akaike information criterion (AIC) value was chosen as the model.

change in MBC was differential in DMS and HMS. In the MNT site the intensity of grazing did not change the MBC, this could be due to the fact that in arid environments (129.9 mm of rain 2016 year) there is a greater cover of woody plants (Table 2) that have recalcitrant carbon in their organic detritus that reaches the soil, which would reduce decomposition rates and indirectly produce a slowdown in nutrient cycles and a decrease in soil microbial biomass regardless of grazing intensity in the environment (Ritchie et al., 1998; Landgraf and Klose, 2002).

The MBC is one of the labile and active fractions of the organic matter present in the soil and has a dynamism given by the seasonality of the climate that is accompanied by the growth of the plants, which was suggested by the interactions of ecological areas * seasons and grazing intensity * stations (Table 4). Our data found differences in MBC between the autumn season (lowest value $409 \mu \mathrm{g} \mathrm{C} \mathrm{g}^{-1}$ soil) and spring (highest value $505 \mu \mathrm{g} \mathrm{g} \mathrm{g}^{-1}$ soil) and there were no differences between summer and winter. The seasonality of MBC is difficult to predict, the highest values occur in different seasons of the year, which depends on each environment, resources (eg labile carbon, water and nutrients), environmental conditions of temperatures and soil humidity and added to the competition for plant resources (Bardgett et al., 2002). This background suggests that in specific environments, there is competition for the resources available in the soil for the growth of plants or microorganisms. We believe that the highest values obtained for MBC in spring in the South Patagonia sites at the beginning of the growing season were given by the less competition with plants that do not yet demand so many resources, coinciding with the higher moisture content of the soil in the beginning of spring and temperature increases. Jaeger et al. (1999) suggested that in mountain ecosystems, microorganisms are most effective when competition from plants has ceased, determining that soil microorganisms may be "saturated with nutrients" 
before there is an amount available for plants (Harte and Kinzig, 1993; Jonasson et al., 1999). In addition, for our environments, we might think of increased root activity at the beginning of the growing season, greater exudation of soluble carbon in the rhizosphere and that this pulse of carbon in the rhizosphere would stimulate microbial growth (Jaeger et al., 1999; Hertenberger et al., 2002; Liebisch et al., 2014).

\subsection{Abundance of fungi and bacteria}

In our study, total bacterial and fungi communities were affected by the type of plant community and soil properties rather than by grazing animals, as demonstrated by Lauber et al. (2008) and Ford et al. (2013). However, the abundance total bacteria in soils in the different ecological areas presented similar values. Similarly, Girvan et al. (2003) found no significant difference in the number of total bacteria in soils due to the equality of textures that the soils had, which could be compared in our sampling sites where all soils had the same sandy textures (Table 3). Buckley and Schmidt (2001) found no differences in the abundance of soil bacteria in their study with different soils, plant communities and different soil management. Contrary, lower number of soil fungi determined in the ecological area of MNT would be given by the characteristics of the soil, including the positive relationship with soil $\mathrm{C}$ and $\mathrm{N}$, and also the inverse relationship with the $\mathrm{pH}$ and soil available $\mathrm{P}$ (Table 6). Therefore, our results are in line with previous researches that have demonstrated that the abundance of fungi is influenced by soil properties, which were different in the ecological areas of our study. Several studies have demonstrated these relationships between soil variables and their influence on the fungi community, confirming that this pattern is consistent at different spatial scales, ecosystems and soil types (Lauber et al., 2008; Siles and Margesin, 2016; Egan et al., 2018).

The long-term grazing intensity in Southern Patagonia environments did not modify the total soil bacteria and fungal communities, as well as the fungi/bacteria ratio in our study. The same was reported by several studies, where they determined that grazing did not change or did so to a lesser extent the abundance of gene copies of fungi and bacteria in grassland soils and also did not alter the fungi/bacteria ratio (Patra et al., 2005; Ford et al., 2013; Egan et al., 2018). However, McCaig et al. (1999) and Grayston et al. (2001) found changes in the structure of bacterial communities in grasslands with greater short-term grazing pressure, determining pulses of feces and urine entering the soil that favored bacterial communities. On the contrary, our sites have extensive and continuous grazing so that these effects are minimized.

The abundance of bacteria and fungi in the soils respond differently in each ecological area according to the years (Fig. $4 \mathrm{AB}$ ), which was observed in previous studies (Lauber et al., 2008; Egan et al., 2018). Annual fluctuations in climatic factors affect the dynamics soil microorganisms, abundance of fungi, bacteria, and the fungi/bacteria ratio between sampling years (Table 4). The microbial communities of fungi and bacteria are highly changeable to variations in the water regime (Maestre et al., 2015) and in our study average annual precipitation varied between sampling years (Fig. 2). Maestre et al. (2015) and Ochoa-Hueso et al. (2018) have shown on a global precipitation gradient that microbial communities were very vulnerable to short-term climatic conditions. Also, events of variations in precipitation determine that microbial communities could be conditioned by the contributions of organic matter associated with the death of fine roots and plant remains (Schwinning and Sala, 2004). The abundance of fungi was more stable in conditions of lower humidity the soil (year 2016) compared to the abundance of bacteria. Leff et al. (2015) and Ochoa-Hueso et al. (2018) propose that variations in soil moisture does not modify the abundance of bacteria and fungi, given the presence of a higher number of drought-resistant bacterial taxa (such as Actinobacteria and Chloroflexi). All this leads us to consider that further research could address how changes in the abundance of the more specific fungal and bacterial groups in a lower taxonomy (phylum, family, genus) could be affected in the soils of Southern Patagonia, given that the total populations of bacteria or fungi remain relatively stable in the soil.

The fungi/bacteria ratio varied between ecological areas, these values are among the ranges reported in previous works for the different forest, pasture, and agricultural soils (Lauber et al., 2008). In part, this would be given by the inverse relationship observed between soil $\mathrm{pH}$ and fungi/bacteria ratio in our study (Table 6), which coincides with that reported by Egan et al. (2018) in grassland soils. Specially, the variation of this ratio is given by decreases in the abundance of fungi mainly, along with increases or little variation in the bacterial populations (Kennedy et al., 2005; De Vries et al., 2006; Weber et al., 2013), which coincides with what was found in our study sites.

\subsection{Soil basal respiration}

Soil potential respiration showed differences between the ecological areas evaluated under the gradient of climate and vegetation. It has also been reported that soil respiration evaluated in different ecological areas of southern Patagonia varied significantly (Peri et al., 2015). The differences found in our results have MNT soils (perennial and woody shrubs) with a lower potential respiration value compared to HMS soils (herbaceous plants) with a higher value. Considering that the contributions of organic remains could be potentially different depending on the species of plants that make up the plant community in the ecological areas (Zeng et al., 2014). The SBR in our data shows a positive correlation with the organic carbon content of the soil as other authors found (Wang et al., 2013). The soil cover obtained shows differences between ecological areas with an HMS > DMS > MNT tendency, which defines the quantity of organic matter from the soil that is breathed as $\mathrm{CO}_{2}$ (Zhao et al., 2016). The higher values of organic carbon could explain the differences found in SBR of HMS area compared to the other ecological areas (Table 3). At global scale, soil respiration rates are positively correlated with average annual air temperatures and average annual precipitation (Raich and Schlesinger, 1992; Wang et al., 2016). This has also been demonstrated in our results, where SBR presented a positive correlation with mean annual temperature and precipitation in the soils of Southern Patagonia (Table 6). Since soil moisture and temperature were controlled during incubation in the laboratory, the difference in respiration rates would have been mainly due to changes in the microbial biomass and substrate quantity and availability (Zheng et al., 2009). Mainly, the response to the increase in SBR in our study was associated with increases in soil organic carbon and soil microbial biomass carbon determined in the ecological areas, which was confirmed by the positive relationship obtained between MBC and SBR (Fig. $8 \mathrm{ABC}$ ). This has been evidenced in several previous studies for different soil types (Wei et al., 2014; Zhao et al., 2017), where heterotopic soil respiration in ecosystems is accompanied by microbial growth (Tucker et al., 2013).

The grazing intensity does not have effect on SBR, although we did see a slight tendency to higher SBR with moderate grazing (Table 5). Thus the response of SBR to grazing is subject to a combined effect with the type of ecosystem (Zou et al., 2007). We found an interaction of ecological areas" grazing on SBR, where in DMS high grazing decreased soil respiration, and the inverse effect occurred in HMS and MNT. This response could be given by the responses that occurred with $\mathrm{MBC}$ in the ecological areas* grazing interactions (Fig. 3A) and further supported by the relationships found between both variables (Fig. $8 \mathrm{C}$ ). Zhao et al. (2017) demonstrated that SBR responses to grazing are related to the size of the microbial community in soil sites with contrasting grazing intensities. Peri et al. (2015) found that in Southern Patagonia grasslands, the soil respiration rate was $30 \%$ higher in moderate grazing compared to intense grazing, attributed to vegetation cover and soil parameters such as organic carbon. Our data do not reflect that grazing affects SBR since the respiration assessed in our results mostly contemplates heterotopic soil respiration. The differences with the data reported for southern Patagonia sites could be explained by the more significant effect of grazing on soil respiration by affecting more the 
plant root respiration, which refers to autotrophic soil respiration. These results somehow support the idea that grazing has differential effects on the autotrophic and heterotrophic components of SBR (Zhao et al., 2017).

\subsection{Microbial metabolic coefficients}

At a global scale, it has been shown that $\mathrm{qCO}_{2}$ differs between ecosystems, with notable variations between biomes, crops, and natural ecosystems, where variations were closely associated with biological factors (such as communities microorganism and plant), followed by soil and climate parameters (Xu et al., 2017). This describes that each environment, ecological areas and with their grazing intensities functions differently. Similarly, in our study, we observed a variation in $\mathrm{qCO}_{2}$ between the ecological areas and a positive correlation between SBR and $\mathrm{qCO}_{2}$ of the soils studied (Table 6). The $\mathrm{qCO}_{2}$ values tend to increase due to stress caused by nutrient limitations, lower quality substrates, and a decrease in the efficiency of microorganisms, factors that seem to be influencing the MNT sites if we observe the soil characteristics (Table 4). Furthermore, the existence of a positive correlation between $\mathrm{SBR}$ and $\mathrm{qCO}_{2}$ could be attributed to the substrates provided by plants (Spehn et al., 2000), indicating that plants can indirectly influence $\mathrm{qCO}_{2}$ by influencing microbial biomass and soil respiration as mentioned above in the effects on these variables. This coincides with our land cover data, where the values of $\mathrm{qCO}_{2}$ accompanied the HMS > DMS > MNT gradient. Evidently, in the arid extreme of the gradient soil microorganisms break down more recalcitrant organic matter to obtain nutrients and energy (Craine et al., 2007), which leads to increased microbial respiration, but this does not translate into increases in $\mathrm{MBC}$ and consequently increases $\mathrm{qCO}_{2}$.

The qM values in our results varied between ecological areas and long-term sheep grazing from 1.75 to $2.50 \%$. Sparling (1992) reported that qM represents between 1 and $4 \%$ of soil organic carbon comparing different soil types, vegetation, and land-use history, describing that differences in $\mathrm{qM}$ values may be due to the conversion efficiency of organic matter into MBC. We found an inverse response between soil organic carbon of the ecological areas and $\mathrm{qM}$, where the ecological areas with higher organic carbon values (Table 3) had the lowest qM values (Fig. 7B). Also, qM decreased with high grazing intensity compared to moderate grazing intensity. Similarly, Holt (1997) found that qM decreased with high grazing in semi-arid grasslands, and Li et al. (2013) have observed that $\mathrm{qM}$ decreased in grasslands subjected to different degrees of degradation from grazing on cold temperate soils. As well as Anderson and Domsch (1990), the correlations obtained for the soils of Southern Patagonia show the existence of interdependence between growth and maintenance of microbial biomass and indicate that a low metabolic quotient corresponds to a high $\mathrm{qM}$, that is: a greater assimilation of organic $\mathrm{C}$ in the microbial biomass and the formation of soil organic matter. This indicates that the alterations generated by grazing in the vegetation (mainly increasing the proportion of recalcitrant $\mathrm{C}$ entering the soil due to changes in plant community), indirectly, had an impact on the soil microorganisms.

\section{Conclusion}

This study reports the first results of the soil microbiological parameters in the main ecological areas of southern Argentine Patagonia. The environmental gradient of the ecological areas showed correlate positively in the microbial biomass, fungal communities, soil respiration and microbial metabolic coefficient, which is attributed to the amount of organic $\mathrm{C}$ in the soil, confirming the importance of this resource for soil microorganisms. High grazing intensity of long-term decreases soil microbial biomass and qM, and this decreases have implications for soil $\mathrm{C}$ accumulation given the relevance of biomass for stable $\mathrm{C}$ formation. Finally, there was a seasonal and interannual dynamic in the MBC and in the bacteria and fungus communities, which were attributed to precipitation and its relationship with increased growth and activity in plants that provide improvements on the soil microbiome. Such knowledge will allow a better understanding in future works about the factors that modulate the structure and microbial function in these ecosystems and, ultimately, the soil C accumulation in the long-term.

\section{Declaration of competing interest}

The authors declare that they have no known competing financial interests or personal relationships that could have appeared to influence the work reported in this paper.

\section{Acknowledgements}

This study was supported by PICT 2016-3659 from the FONCYT agency government of Argentine. We thank the cooperation of Leonardo Huertas for his help in the field sample collection. We also thank fields Chali aike, Los pozos, Monte dinero, Kilik aike, El condor y Laguna de oro for allowing us to work on his ranches.

\section{Appendix A. Supplementary data}

Supplementary data associated with this article can be found, in the online version, at https://doi.org/10.1016/j.jaridenv.2020.104300.

\section{Author contributions}

Toledo, Santiago: Investigation, Methodology, Writing-review draft. Peri, Pablo L.: Conceptualization, Investigation, Writing-review and editing.

Correa, Olga S.: Resources, Writing-review and editing.

Gargaglione, Veronica: Methodology, Resources, Writing-review and editing.

Gonzalez-Polo Marina: Conceptualization, Writing-review and editing.

\section{References}

Abdu, N., Abdullahi, A.A., Abdulkadir, A., 2017. Heavy metals and soil microbes. Environ. Chem. Lett. 15 (1), 65-84. https://doi.org/10.1007/s10311-016-0587-x. Anderson, T.H., Domsch, K.H., 1990. Application of eco-physiological quotients $\left(\mathrm{qCO}_{2}\right.$ and $\mathrm{qD}$ ) on microbial biomasses from soils of different cropping histories. Soil Biol. Biochem. 22 (2), 251-255. https://doi.org/10.1016/0038-0717(90)90094-G.

Anderson, T.H., Domsch, K.H., 1993. The metabolic quotient for $\mathrm{CO}_{2}\left(\mathrm{qCO}_{2}\right)$ as a specific activity parameter to assess the effects of environmental conditions, such as $\mathrm{pH}$, on the microbial biomass of forest soils. Soil Biol. Biochem. 25 (3), 393-395.

Araújo, A.D., Santos, V.B., Monteiro, R.T.R., 2008. Responses of soil microbial biomass and activity for practices of organic and conventional farming systems in Piauí state, Brazil. Eur. J. Soil Biol. 44 (2), 225-230. https://doi.org/10.1016/j. ejsobi.2007.06.001.

Augustine, D.J., McNaughton, S.J., 1998. Ungulate effects on the functional species composition of plant communities: herbivore selectivity and plant tolerance. J. Wildl. Manag. 62, 1165-1183. https://doi.org/10.2307/3801981.

Bais, H.P., Weir, T.L., Perry, L.G., Gilroy, S., Vivanco, J.M., 2006. The role of root exudates in rhizosphere interactions with plants and other organisms. Annu. Rev. Plant Biol. 57, 233-266. https://doi.org/10.1146/annurev. arplant.57.032905.105159.

Bardgett, R.D., Wardle, D.A., Yeates, G.W., 1998. Linking above-ground and belowground interactions: how plant responses to foliar herbivory influence soil organisms. Soil Biol. Biochem. 30, 1867-1878. https://doi.org/10.1016/S00380717(98)00069-8.

Bardgett, R.D., Jones, A.C., Jones, D.L., Kemmitt, S.J., Cook, R., Hobbs, P.J., 2001. Soil microbial community patterns related to the history and intensity of grazing in submontane ecosystems. Soil Biol. Biochem. 33 (12-13), 1653-1664. https://doi.org/ 10.1016/S0038-0717(01)00086-4.

Bardgett, R.D., Streeter, T.C., Cole, L., Hartley, I.R., 2002. Linkages between soil biota, nitrogen availability, and plant nitrogen uptake in a mountain ecosystem in the Scottish Highlands. Appl. Soil Ecol. 19 (2), 121-134. https://doi.org/10.1016/ S0929-1393(01)00188-3.

Bisigato, A.J., Bertiller, M.B., 2004. Temporal and micro-spatial patterning of seedling establishment. Consequences for patch dynamics in the southern Monte, Argentina. Plant Ecol. 174 (2), 235-246. https://doi.org/10.1023/B: VEGE.0000049101.30809.27. 
Buckley, D.H., Schmidt, T.M., 2001. The structure of microbial communities in soil and the lasting impact of cultivation. Microb. Ecol. 42 (1), 11-21. https://doi.org/ 10.1007/s002480000108.

Craine, J.M., Morrow, C., Fierer, N., 2007. Microbial nitrogen limitation increases decomposition. Ecology 88 (8), 2105-2113. https://doi.org/10.1890/06-1847.1.

De Vries, F.T., Hoffland, E., van Eekeren, N., Brussaard, L., Bloem, J., 2006. Fungal/ bacterial ratios in grasslands with contrasting nitrogen management. Soil Biol. Biochem. 38 (8), 2092-2103. https://doi.org/10.1016/j.soilbio.2006.01.008.

Dennis, P.G., Miller, A.J., Hirsch, P.R., 2010. Are root exudates more important than other sources of rhizodeposits in structuring rhizosphere bacterial communities? FEMS Microbiol. Ecol. 72 (3), 313-327. https://doi.org/10.1111/j.15746941.2010.00860.x.

Di Rienzo, J.A., Casanoves, F., Balzarini, M.G., Gonzalez, L., Tablada, M., Robledo, C.W., 2013. Infostat Versión 2013. Córdoba, Argentina: Grupo InfoStat, FCA. Universidad Nacional de Córdoba.

Dube, F., Zagal, E., Stolpe, N., Espinosa, M., 2009. The influence of land-use change on the organic carbon distribution and microbial respiration in a volcanic soil of the Chilean Patagonia. For. Ecol. Manag. 257 (8), 1695-1704. https://doi.org/10.1016/ j.foreco.2009.01.044.

Egan, G., Zhou, X., Wang, D., Jia, Z., Crawley, M.J., Fornara, D., 2018. Long-term effects of grassland management on soil microbial abundance: implications for soil carbon and nitrogen storage. Biogeochemistry 141 (2), 213-228. https://doi.org/10.1007/ s10533-018-0515-1.

Fierer, N., Jackson, J.A., Vilgalys, R., Jackson, R.B., 2005. Assessment of soil microbial community structure by use of taxon-specific quantitative PCR assays. Appl. Environ. Microbiol. 71 (7), 4117-4120. https://doi.org/10.1128/AEM.71.7.4117-4120.2005.

Ford, H., Rousk, J., Garbutt, A., Jones, L., Jones, D.L., 2013. Grazing effects on microbial community composition, growth and nutrient cycling in salt marsh and sand dune grasslands. Biol. Fertil. Soils 49 (1), 89-98. https://doi.org/10.1007/s00374-0120721-2.

Franzluebbers, A.J., Hons, F.M., Zuberer, D.A., 1995. Soil organic carbon, microbial biomass, and mineralizable carbon and nitrogen in sorghum. Soil Sci. Soc. Am. J. 59 (2), 460-466. https://doi.org/10.2136/sssaj1995.03615995005900020027x.

Franzluebbers, A.J., Haney, R.L., Honeycutt, C.W., Arshad, M.A., Schomberg, H.H., Hons, F.M., 2001. Climatic influences on active fractions of soil organic matter. Soil Biol. Biochem. 33 (7-8), 1103-1111. https://doi.org/10.1016/S0038-0717(01) 00016-5.

Girvan, M.S., Bullimore, J., Pretty, J.N., Osborn, A.M., Ball, A.S., 2003. Soil type is the primary determinant of the composition of the total and active bacterial communities in arable soils. Appl. Environ. Microbiol. 69 (3), 1800-1809. https:// doi.org/10.1128/AEM.69.3.1800-1809.2003.

Golluscio, R.A., Austin, A.T., Martínez, G.C.G., Gonzalez-Polo, M., Sala, O.E., Jackson, R. B., 2009. Sheep grazing decreases organic carbon and nitrogen pools in the Patagonian steppe: combination of direct and indirect effects. Ecosystems 12 (4), 686-697. https://doi.org/10.1007/s10021-009-9252-6.

Grayston, S.J., Griffith, G.S., Mawdsley, J.L., Campbell, C.D., Bardgett, R.D., 2001. Accounting for variability in soil microbial communities of temperate upland grassland ecosystems. Soil Biol. Biochem. 33 (4-5), 533-551. https://doi.org/ 10.1016/S0038-0717(00)00194-2.

Hamilton, E.W., Frank, D.A., 2001. Can plants stimulate soil microbes and their own nutrient supply? Evidence from a grazing tolerant grass. Ecology 82, 2397-2402. https://doi.org/10.1890/0012-9658(2001)082[2397:CPSSMA]2.0.CO;2.

Harte, J., Kinzig, A.P., 1993. Mutualism and competition between plants and decomposers: implications for nutrient allocation in ecosystems. Am. Nat. 141 (6), 829-846. https://doi.org/10.1086/285511.

Hertenberger, G., Zampach, P., Bachmann, G., 2002. Plant species affect the concentration of free sugars and free amino acids in different types of soil. J. Plant Nutr. Soil Sci. 165 (5), 557-565. https://doi.org/10.1002/1522-2624(200210)165: $5<557::$ AID-JPLN1111557> 3.0.CO;2-G.

Holland, E.A., Parton, W.J., Detling, J.K., Coppock, D.L., 1992. Physiological responses of plant populations to herbivory and their consequences for ecosystem nutrient flow. Am. Nat. 140 (4), 685-706. https://doi.org/10.1086/285435.

Holland, J.N., Cheng, W., Crossley, D.A., 1996. Herbivore-induced changes in plant carbon allocation: assessment of below-ground C fluxes using carbon-14. Oecologia 107 (1), 87-94. https://doi.org/10.1007/BF00582238.

Holt, J.A., 1997. Grazing pressure and soil carbon, microbial biomass and enzyme activities in semi-arid northeastern Australia. Appl. Soil Ecol. 5, 143-149. https:// doi.org/10.1016/S0929-1393(96)00145-X.

Jaeger, C.H., Monson, R.K., Fisk, M.C., Schmidt, S.K., 1999. Seasonal partitioning of nitrogen by plants and soil microorganisms in an alpine ecosystem. Ecology 80 (6), 1883-1891. https://doi.org/10.1890/0012-9658(1999)080[1883:SPONBP]2.0.CO; 2.

Jobbágy, E., Sala, O.E., Paruelo, J.M., 2002. Patterns and controls of primary production in the Patagonian steppe: a remote sensing approach. Ecology 83 (2), 307-319. https://doi.org/10.1890/0012-9658(2002)083[0307:PACOPP]2.0.CO;2.

Joergensen, R.G., 1996. The fumigation-extraction method to estimate soil microbial biomass: calibration of the kEC value. Soil Biol. Biochem. 28 (1), 25-31. https://doi. org/10.1016/0038-0717(95)00102-6.

Jonasson, S., Michelsen, A., Schmidt, I.K., 1999. Coupling of nutrient cycling and carbon dynamics in the Arctic, integration of soil microbial and plant processes. Appl. Soil Ecol. 11, 135-146. https://doi.org/10.1016/S0929-1393(98)00145-0.

Kennedy, N., Edwards, S., Clipson, N., 2005. Soil bacterial and fungal community structure across a range of unimproved and semi-improved upland grasslands. Microb. Ecol. 50 (3), 463-473. https://doi.org/10.1007/s00248-005-0256-2.

Landgraf, D., Klose, S., 2002. Mobile and readily available C and $\mathrm{N}$ fractions and their relationship to microbial biomass and selected enzyme activities in a sandy soil under different management systems. J. Plant Nutr. Soil Sci. 165, 9-16. https://doi. org/10.1002/1522-2624(200202)165:1<9::AID-JPLN9>3.0.CO;2-O.

Lauber, C.L., Strickland, M.S., Bradford, M.A., Fierer, N., 2008. The influence of soil properties on the structure of bacterial and fungal communities across land-use types. Soil Biol. Biochem. 40 (9), 2407-2415. https://doi.org/10.1016/j. soilbio.2008.05.021.

Leff, J.W., Jones, S.E., Prober, S.M., Barberán, A., Borer, E.T., Firn, J.L., McCulley, R.L., 2015. Consistent responses of soil microbial communities to elevated nutrient inputs in grasslands across the globe. Proc. Natl. Acad. Sci. Unit. States Am. 112 (35), 10967-10972. https://doi.org/10.1073/pnas.1508382112.

Lei, T., Pang, Z., Wang, X., Li, L., Fu, J., Kan, G., Shao, C., 2016. Drought and carbon cycling of grassland ecosystems under global change: a review. Water 8 (10), 460 https://doi.org/10.3390/w8100460.

Levy, E.B., Madden, E.A., 1933. The point method of pasture analysis. N. Z. J. Agric. 46 (5), 267-179.

Li, Y., Dong, S., Wen, L., Wang, X., Wu, Y., 2013. The effects of fencing on carbon stocks in the degraded alpine grasslands of the Qinghai-Tibetan Plateau. J. Environ. Manag. 128, 393-399. https://doi.org/10.1016/j.jenvman.2013.05.058.

Liao, J.D., Boutton, T.W., 2008. Soil microbial biomass response to woody plant invasion of grassland. Soil Biol. Biochem. 40 (5), 1207-1216. https://doi.org/10.1016/j. soilbio.2007.12.018.

Liebisch, F., Keller, F., Huguenin-Elie, O., Frossard, E., Oberson, A., Bünemann, E.K., 2014. Seasonal dynamics and turnover of microbial phosphorusin a permanent grassland. Biol. Fertil. Soils 50 (3), 465-475. https://doi.org/10.1007/s00374-0130868-5.

Lin, B., Zhao, X., Zheng, Y., Qi, S., Liu, X., 2017. Effect of grazing intensity on protozoan community, microbial biomass, and enzyme activity in an alpine meadow on the Tibetan Plateau. J. Soils Sediments 17 (12), 2752-2762. https://doi.org/10.1007/ s11368-017-1695-3.

Liu, N., Zhang, Y., Chang, S., Kan, H., Lin, L., 2012. Impact of grazing on soil carbon and microbial biomass in typical steppe and desert steppe of Inner Mongolia. PLoS One 7 (5). https://doi.org/10.1371/journal.pone.0036434.

Liu, N., Kan, H.M., Yang, G.W., Zhang, Y.J., 2015. Changes in plant, soil, and microbes in a typical steppe from simulated grazing: explaining potential change in soil C. Ecol. Monogr. 85 (2), 269-286. https://doi.org/10.1890/14-1368.1.

Maestre, F.T., Delgado-Baquerizo, M., Jeffries, T.C., Eldridge, D.J., Ochoa, V., Gozalo, B., Bowker, M.A., 2015. Increasing aridity reduces soil microbial diversity and abundance in global drylands. Proc. Natl. Acad. Sci. Unit. States Am. 112 (51), 15684-15689. https://doi.org/10.1073/pnas.1516684112.

Manzoni, S., Porporato, A., 2009. Soil carbon and nitrogen mineralization: theory and models across scales. Soil Biol. Biochem. 41 (7), 1355-1379. https://doi.org/ 10.1016/j.soilbio.2009.02.031.

McCaig, A.E., Glover, L.A., Prosser, J.I., 1999. Molecular analysis of bacterial community structure and diversity in unimproved and improved upland grass pastures. Appl. Environ. Microbiol. 65 (4), 1721-1730. https://doi.org/10.1128/AEM.65.4.17211730.1999.

Noellemeyer, E., Frank, F., Alvarez, C., Morazzo, G., Quiroga, A., 2008. Carbon contents and aggregation related to soil physical and biological properties under a land-use sequence in the semiarid region of central Argentina. Soil Tillage Res. 99 (2), 179-190. https://doi.org/10.1016/j.still.2008.02.003.

Northup, B.K., Brown, J.R., Holt, J.A., 1999. Grazing impacts on the spatial distribution of soil microbial biomass around tussock grasses in a tropical grassland. Appl. Soil Ecol. 13, 259-270. https://doi.org/10.1016/S0929-1393(99)00039-6.

Ochoa Hueso, R., Collins, S.L., Delgado-Baquerizo, M., Hamonts, K., Pockman, W.T., Sinsabaugh, R.L., Power, S.A., 2018. Drought consistently alters the composition of soil fungal and bacterial communities in grasslands from two continents. Global Change Biol. 24 (7), 2818-2827. https://doi.org/10.1111/gcb.14113.

Patra, A.K., Abbadie, L., Clays-Josserand, A., Degrange, V., Grayston, S.J., Loiseau, P., Poly, F., 2005. Effects of grazing on microbial functional groups involved in soil $\mathrm{N}$ dynamics. Ecol. Monogr. 75 (1), 65-80. https://doi.org/10.1890/03-0837.

Peri, P.L., 2011. Carbon storage in cold temperate ecosystems in southern Patagonia, Argentina. In: Islam, Atazadeh (Ed.), Biomass and Remote Sensing of Biomass. InTech, Lijeka, Croatia, pp. 213-226.

Peri, P.L., Lencinas, M.V., Martinez Pastur, G., Wardell-Johnson, G.W., Lasagno, R., 2013. Diversity patterns in the steppe of Argentinean Southern Patagonia: environmental drivers and impact of grazing. In: Morales Prieto, M.B., Traba Díaz, J. (Eds.), En: Steppe Ecosystems: Biological Diversity, Management and Restoration, vol. 346. NOVA Science Publishers, Inc., New York, USA, ISBN 978-1-62808-298-2, pp. 73-95 (Chapter 4).

Peri, P.L., Bahamonde, H., Christiansen, R., 2015. Soil respiration in Patagonian semiarid grasslands under contrasting environmental and use conditions. J. Arid Environ. 119, 1-8. https://doi.org/10.1016/j.jaridenv.2015.03.008.

Peri, P.L., Ladd, B., Lasagno, R.G., Pastur, G.M., 2016a. The effects of land management (grazing intensity) vs. the effects of topography, soil properties, vegetation type, and climate on soil carbon concentration in Southern Patagonia. J. Arid Environ. 134, 73-78. https://doi.org/10.1016/j.jaridenv.2016.06.017.

Peri, P.L., Lencinas, M.V., Bousson, J., Lasagno, R., Soler, R., Bahamonde, H., Pastur, G. M., 2016b. Biodiversity and ecological long-term plots in Southern Patagonia to support sustainable land management: the case of PEBANPA network. J. Nat. Conserv. 34, 51-64. https://doi.org/10.1016/j.jnc.2016.09.003.

Peri, P.L., Rosas, Y.M., Ladd, B., Toledo, S., Lasagno, R.G., Martínez Pastur, G., 2018. Modelling soil carbon content in South Patagonia and evaluating changes according to climate, vegetation, desertification and grazing. Sustainability 10 (2), 438. https://doi.org/10.3390/su10020438.

Ponge, J.F., 2015. The soil as an ecosystem. Biol. Fertil. Soils 51 (6), 645-648. https:// doi.org/10.1007/s00374-015-1016-1. 
Prevost-Boure, N.C., Christen, R., Dequiedt, S., Mougel, C., Lelievre, M., Jolivet, C., Ranjard, L., 2011. Validation and application of a PCR primer set to quantify fungal communities in the soil environment by real-time quantitative PCR. PloS One 6 (9), e24166. https://doi.org/10.1371/journal.pone.0024166.

Raich, J.W., Schlesinger, W.H., 1992. The global carbon dioxide flux in soil respiration and its relationship to vegetation and climate. Tellus B 44 (2), 81-99. https://doi. org/10.1034/j.1600-0889.1992.t01-1-00001.x.

Raiesi, F., Asadi, E., 2006. Soil microbial activity and litter turnover in native grazed and ungrazed rangelands in a semiarid ecosystem. Biol. Fertil. Soils 43 (1), 76-82. https://doi.org/10.1007/s00374-005-0066-1.

Reeder, J.D., Schuman, G.E., 2002. Influence of livestock grazing on C sequestration in semi-arid mixed-grass and short-grass rangelands. Environ. Pollut. 116 (3), 457-463. https://doi.org/10.1016/S0269-7491(01)00223-8.

Richter, A., Huallacháin, D.Ó., Doyle, E., Clipson, N., Van Leeuwen, J.P., Heuvelink, G.B. Creamer, R.E., 2018. Linking diagnostic features to soil microbial biomass and respiration in agricultural grassland soil: a large-scale study in Ireland. Eur. J. Soil Sci. 69 (3), 414-428. https://doi.org/10.1111/ejss.12551.

Ritchie, M.E., Tilman, D., Knops, J.M., 1998. Herbivore effects on plant and nitrogen dynamics in oak savanna. Ecology 79 (1), 165-177. https://doi.org/10.1890/0012 9658(1998)079[0165:HEOPAN]2.0.CO;2.

Robertson, G.P., Wedin, D., Groffman, P.M., Blair, J.M., Holland, E.A., Nadelhoffer, K.J., Harris, D., 1999. Soil Carbon and nitrogen availability nitrogen mineralization, nitrification and soil respiration potentials. In: Robertson, G.P., Coleman, D.C. Bledsoes, C.S., Sollins, P. (Eds.), Standard Soil Methods for Long Term Ecological Research. Oxford University Press, New York.

Schloter, M., Nannipieri, P., Sørensen, S.J., van Elsas, J.D., 2018. Microbial indicators for soil quality. Biol. Fertil. Soils 54 (1), 1-10. https://doi.org/10.1007/s00374-0171248-3.

Schwinning, S., Sala, O.E., 2004. Hierarchy of responses to resource pulses in arid and semi-arid ecosystems. Oecologia 141 (2), 211-220. https://doi.org/10.1007/ s00442-004-1520-8.

Siles, J.A., Margesin, R., 2016. Abundance and diversity of bacterial, archaeal, and fungal communities along an altitudinal gradient in alpine forest soils: what are the driving factors? Microb. Ecol. 72 (1), 207-220. https://doi.org/10.1007/s00248016-0748-2.

Sparling, G.P., 1992. Ratio of microbial biomass carbon to soil organic carbon as a sensitive indicator of changes in soil organic matter. Soil Res. 30 (2), 195-207. https://doi.org/10.1071/SR9920195.

Spehn, E.M., Joshi, J., Schmid, B., Alphei, J., Körner, C., 2000. Plant diversity effects on soil heterotrophic activity in experimental grassland ecosystems. Plant Soil 224, 217-230. https://doi.org/10.1023/A:1004891807664.

Stark, S., Eskelinen, A., Männistö, M.K., 2012. Regulation of microbial community composition and activity by soil nutrient availability, soil $\mathrm{pH}$, and herbivory in the tundra. Ecosystems 15 (1), 18-33. https://doi.org/10.1007/s10021-011-9491-1.

Teague, W.R., Dowhower, S.L., Baker, S.A., Haile, N., Delaune, P.B., Conover, D.M., 2011. Grazing management impacts on vegetation, soil biota and soil chemical, physical and hydrological properties in tall grass prairie. Agric. Ecosyst. Environ. 141 (3-4), 310-322. https://doi.org/10.1016/j.agee.2011.03.009.
Truu, M., Truu, J., Ivask, M., 2008. Soil microbiological and biochemical properties for assessing the effect of agricultural management practices in Estonian cultivated soils. Eur. J. Soil Biol. 44 (2), 231-237. https://doi.org/10.1016/j.ejsobi.2007.12.003.

Tucker, C.L., Bell, J., Pendall, E., Ogle, K., 2013. Does declining carbon-use efficiency explain thermal acclimation of soil respiration with warming? Global Change Biol. 19, 252e263. https://doi.org/10.1111/gcb.12036.

Vance, E.D., Brookes, P.C., Jenkinson, D.S., 1987. An extraction method for measuring soil microbial biomass C. Soil Biol. Biochem. 19, 703-707. https://doi.org/10.1016/ 0038-0717(87)90052-6.

Wang, W., Zeng, W., Chen, W., Zeng, H., Fang, J., 2013. Soil respiration and organic carbon dynamics with grassland conversions to woodlands in temperate China. PloS One 8 (8), e71986. https://doi.org/10.1371/journal.pone.0071986.

Wang, Z., Ji, L., Hou, X., Schellenberg, M.P., 2016. Soil respiration in semiarid temperate grasslands under various land management. PloS One 11 (1), e0147987. https://doi. org/10.1371/journal.pone.0147987.

Weber, C.F., Vilgalys, R., Kuske, C.R., 2013. Changes in fungal community composition in response to elevated atmospheric $\mathrm{CO} 2$ and nitrogen fertilization varies with soil horizon. Front. Microbiol. 4, 78. https://doi.org/10.3389/fmicb.2013.00078.

Wei, H., Guenet, B., Vicca, S., Nunan, N., Abdelgawad, H., Pouteau, V., 2014. Thermal acclimation of organic matter decomposition in an artificial forest soil is related to shifts in microbial community structure. Soil Biol. Biochem. 71, 1-12. https://doi. org/10.1016/j.soilbio.2014.01.003.

Xu, X., Schimel, J.P., Janssens, I.A., Song, X., Song, C., Yu, G., Thornton, P.E., 2017. Global pattern and controls of soil microbial metabolic quotient. Ecol. Monogr. 87 (3), 429-441. https://doi.org/10.1002/ecm.1258.

Zeng, X., Zhang, W., Shen, H., Cao, J., Zhao, X., 2014. Soil respiration response in different vegetation types at Mount Taihang, China. Catena 116, 78-85. https://doi. org/10.1016/j.catena.2013.12.018.

Zhao, C., Miao, Y., Yu, C., Zhu, L., Wang, F., Jiang, L., Hui, D., Wan, S., 2016. Soil microbial community composition and respiration along an experimental precipitation gradient in a semiarid steppe. Sci. Rep. 6 (1), 1-9. https://doi.org/ 10.1038 /srep 24317.

Zhao, F., Ren, C., Shelton, S., Wang, Z., Pang, G., Chen, J., Wang, J., 2017. Grazing intensity influence soil microbial communities and their implications for soil respiration. Agric. Ecosyst. Environ. 249, 50-56. https://doi.org/10.1016/j. agee.2017.08.007.

Zheng, Z.M., Yu, G.R., Fu, Y.L., Wang, Y.S., Sun, X.M., Wang, Y.H., 2009. Temperature sensitivity of soil respiration is affected by prevailing climatic conditions and soil organic carbon content: a trans-China based case study. Soil Biol. Biochem. 41 (7), 1531-1540. https://doi.org/10.1016/j.soilbio.2009.04.013.

Zhou, G., Zhou, X., He, Y., Shao, J., Hu, Z., Liu, R., Hosseinibai, S., 2017. Grazing intensity significantly affects belowground carbon and nitrogen cycling in grassland ecosystems: a meta-analysis. Global Change Biol. 23 (3), 1167-1179. https://doi. org/10.1111/gcb.13431.

Zou, C., Wang, K., Wang, T., Xu, W., 2007. Overgrazing and soil carbon dynamics in eastern Inner Mongolia of China. Ecol. Res. 22 (1), 135-142. https://doi.org/ 10.1007/s11284-006-0009-9. 